NBER WORKING PAPER SERIES

OVERCOMING THE COMMON POOL PROBLEM THROUGH VOLUNTARY COOPERATION: THE RISE AND FALL OF A FISHERY COOPERATIVE

\author{
Robert T. Deacon \\ Dominic P. Parker \\ Christopher Costello \\ Working Paper 16339 \\ http://www.nber.org/papers/w16339
}

NATIONAL BUREAU OF ECONOMIC RESEARCH

1050 Massachusetts Avenue

Cambridge, MA 02138

September 2010

We are indebted to Mark Stichert of the Alaska Department of Fish and Game for helping us acquire necessary data. This research was supported by a grant from the Paul Allen Family Foundation. The views expressed herein are those of the authors and do not necessarily reflect the views of the National Bureau of Economic Research.

NBER working papers are circulated for discussion and comment purposes. They have not been peerreviewed or been subject to the review by the NBER Board of Directors that accompanies official NBER publications.

(C) 2010 by Robert T. Deacon, Dominic P. Parker, and Christopher Costello. All rights reserved. Short sections of text, not to exceed two paragraphs, may be quoted without explicit permission provided that full credit, including (C) notice, is given to the source. 
Overcoming the common pool problem through voluntary cooperation: the rise and fall of a fishery cooperative Robert T. Deacon, Dominic P. Parker, and Christopher Costello

NBER Working Paper No. 16339

September 2010

JEL No. Q22

\begin{abstract}
We analyze a seldom used, but highly promising form of rights-based management over common pool resources that involves the self-selection of heterogeneous fishermen into sectors. The fishery management regime assigns one portion of an overall catch quota to a voluntary cooperative, with the remainder exploited as a commons by those choosing to fish independently. Data from an Alaska commercial salmon fishery confirm our model's key predictions, that the co-op would facilitate the consolidation of fishing effort, coordination of harvest activities, sharing of information and provision of shared infrastructure. We estimate that the resulting rent gains were at least 25\%. A lawsuit filed by two disgruntled independents led to the co-op's demise, an outcome also predicted by our model. Our analysis provides guidance for designing fishery reform that leads to Pareto improvements for fishermen of all skill levels, which suggests a structure that enables reform without losers.
\end{abstract}

Robert T. Deacon

2127 North Hall

University of California

Santa Barbara, CA 93106-9210

deacon@econ.ucsb.edu

Dominic P. Parker

Montana State University

P.O. Box 172920

Bozeman, MT 59717-2920

dominic.parker@montana.edu
Christopher Costello

Bren School of Environmental

Science \& Management

University of California, Santa Barbara

Santa Barbara, CA 93106

and NBER

costello@bren.ucsb.edu 


\title{
Overcoming the Common Pool Problem through Voluntary Cooperation: \\ The Rise and Fall of a Fishery Cooperative*
}

\author{
Robert T. Deacon ${ }^{ \pm \dagger}$, Dominic P. Parker ${ }^{\ddagger}$, and Christopher Costello \\ ${ }^{ \pm}$University of California, Santa Barbara \\ ॠMontana State University \\ "National Bureau of Economic Research \\ ${ }^{\dagger}$ Resources for the Future
}

\begin{abstract}
We analyze a seldom used, but highly promising form of rights-based management over common pool resources that involves the self-selection of heterogeneous fishermen into sectors. The fishery management regime assigns one portion of an overall catch quota to a voluntary cooperative, with the remainder exploited as a commons by those choosing to fish independently. Data from an Alaska commercial salmon fishery confirm our model's key predictions, that the co-op would facilitate the consolidation of fishing effort, coordination of harvest activities, sharing of information and provision of shared infrastructure. We estimate that the resulting rent gains were at least $25 \%$. A lawsuit filed by two disgruntled independents led to the co-op's demise, an outcome also predicted by our model. Our analysis provides guidance for designing fishery reform that leads to Pareto improvements for fishermen of all skill levels, which suggests a structure that enables reform without losers.
\end{abstract}

JEL classifications: Q22, D23, L23

\section{Introduction}

The common pool problem illustrates a key insight from economics - that individually rational behavior can lead to a suboptimal outcome. ${ }^{1}$ After decades of study and years of practical experience, there is broad consensus that property rights-based management can solve the common pool problem in a variety of contexts. ${ }^{2}$ Ironically, however, little progress has been

\footnotetext{
* Our respective email addresses are deacon@econ.ucsb.edu, dominic.parker@montana.edu and costello@bren.ucsb.edu. We are indebted to Mark Stichert of the Alaska Department of Fish and Game for helping us acquire necessary data. This research was supported by a grant from the Paul Allen Family Foundation.

${ }^{1}$ Two seminal contributions are Gordon (1954) and Scott (1955).

${ }^{2}$ By 'rights-based management' we mean creation of rights to the good, or bad, in question and reliance on market transactions to allocate these rights. By 'solve' we mean that such systems can allocate a given quantity efficiently. Applications include markets for rights to emit sulfur dioxide and other air pollutants
} 
made implementing this solution in the fishery, the iconic example of a common pool resource; despite the collapse of economically important fisheries around the world, management schemes based on granting quantitative rights to the catch are used in less than $2 \%$ of the world's fisheries. ${ }^{3}$ Apparently, implementation of rights-based management of fisheries and other common pool resources has been hindered by the transactions costs involved in shifting away from an existing regulatory regime. ${ }^{4}$ In the fishery, individuals who are well-suited to competing under an existing regime have incentives to block the transition. ${ }^{5}$

We examine a variant of rights-based management that has the potential to overcome this incentive to block. In the system we examine the regulator assigns a portion of the aggregate catch to a group of harvesters, formed voluntarily, to manage as the group decides. Those choosing not to join continue to fish independently, under the prior regime. Under conditions we spell out, the transition to a cooperative-based fishery management regime can be Pareto improving, a feature that enables 'reform without losers' in the sense of Lau, et al. (2000). These authors point out that designing policy reform to be Pareto improving (by protecting status quo rents under the preexisting regime) minimizes political opposition; they cite this as a feature that enabled China's economic reforms over the last 30 years, as well as less sweeping policy shifts elsewhere. ${ }^{6}$

The policy of assigning a portion of the allowed catch to a group that is empowered by contract to allocate its members' resources in a unified way gives the co-op the same contractual structure as the firm. As Coase (1937) pointed out, allocating inputs centrally via contracts with a manager rather than across markets allows an enterprise with this structure to capture gains from coordination without incurring excessive transactions costs. ${ }^{7}$ Alchian and Demsetz (1972) extended this insight, arguing that the gains to coordination are greatest when production requires

\footnotetext{
as well as greenhouse gasses. See Tietenberg (2002) for a review. On the use of a rights-based regime to manage common pool groundwater, see Provencher and Burt (1994).

${ }^{3}$ Costello, et al. (2008). These systems, often called 'catch share' or 'individual transferable quota' systems, have been shown to yield significant efficiency gains. The individual transferable quota, or ITQ, is a widely promoted rights-based system in which quantitative rights to portions of a fixed total catch are assigned to individuals and may be traded. The collapse of fisheries is described and documented in several studies (see, Halpern et al. 2008; Myers and Worm, 2003; Jackson et al. 2001; Worm et al. 2006). While pollution, climate change, and habitat damage have all been implicated, poor governance structures are widely believed to be the root cause (Beddington et al. 2007; Hilborn et al 2005, Wilen 2005).

${ }^{4}$ Libecap and Wiggins (1984) and Wiggins and Libecap (1985) show that rights-based approaches to managing common oil reservoirs also suffer from scant implementation due to transactions costs.

${ }^{5}$ Compounding the problem, inefficient fishery regulation can induce excessive investment in vessels and processing plants. Owners of this capital have incentives to resist regulatory change that would eliminate or impair its value.

${ }^{6}$ We focus on Pareto improvements without side payments. Conditions ensuring a Pareto improvement clearly depend on the form of the pre-existing regulation.

${ }^{7}$ In fact, Coase (1937) refers to the firm's manager as an 'entrepreneur-coordinator'.
} 
the use of a shared input. Use of a shared input is a hallmark of commercial fishing and other activities based on common pool extraction, as the pool itself is jointly used by all participants. ${ }^{8}$

We contribute to the literature on common pool management by developing a model of this alternative regime and testing its implications with available data. Our analysis is motivated by the formation of a salmon harvesting cooperative that operated in Chignik, Alaska during 2002-2004. Data from this fishery and other nearby fisheries form the basis for empirical tests. Originally, the Chignik sockeye salmon fishery was regulated by a limit on licenses and by closing the season when a target level of catch was reached, a common form of management known to induce a race to fish. ${ }^{9}$ Allowing a voluntary co-op to form, with non-joiners fishing as before, led to a dramatic increase in the profitability of the fishery - by causing changes in the length of the fishing season, the number of permit holders who actually fished, the spatial and temporal deployment of effort, and the coordination of effort across fishermen. The co-op's demise in 2005, the result of a lawsuit, is an important part of the story that we examine in some detail. Our model and empirical analysis focus on these behavioral shifts and on whether the regime change was (or could have been) Pareto improving.

Two aspects of the regime we examine, the voluntary joining decision and assignment of some catch rights to a group rather than entirely to separate individuals, are noteworthy and link our analysis to broader literatures. Because joining the co-op is voluntary, the disgruntled can opt out and this makes Pareto improvements easier to attain. This feature also implies, however, that the final outcome generally will not be Pareto optimal. The reason is that, with variations in fishing skill, some fishermen will opt to stay with the original regime which is known to be inefficient. The co-op we examine forms voluntarily and provides excludable, shared inputs for members, i.e., club goods. As a consequence our theory and empirical work contribute to the broad literature on the theory of clubs (Cornes and Sandler, 1996). In addition to forming voluntarily, the co-op coordinates its members' decisions, while non-joiners form an uncoordinated fringe. Models of cartel formation (d'Aspremont, et al., 1983) and international environmental agreements (Barrett, 1994; Kolstad and Ulph, 2008) have the same structure, so our results may make useful contributions to empirical knowledge of how such structures function. The fishery cooperative also shares important features with worker-formed teamsvoluntarily formed groups of workers that coordinate members' actions and are paid on the basis of overall team productivity (Hamilton, et al. 2003). Our analysis sheds light on two central

\footnotetext{
${ }^{8}$ Scott (2000) argues persuasively for assigning management responsibilities to fishery-wide firms or harvester associations for similar reasons. Scott also noted gains from coordinating harvesting activity in his original (Scott, 1955) contribution, but this point was overlooked in the literature that followed.

${ }^{9}$ The 'race' and its consequences have been extensively documented in the literature; see Wilen (2005).
} 
questions from the worker-team literature: the productivity gains attainable by groups of workers who self-coordinate, and the distinguishing attributes of those who choose to join.

Several features of the Chignik experiment make it ideal for empirical analysis of these aspects of regime change. First, each sector fished at separate times that were determined by fishery regulators; the co-op as a coordinated fleet and the independents as competitive individuals. This feature allows us to cleanly compare how within-season behavior differed under cooperative and competitive fishing. ${ }^{10}$ Second, there were two regime shifts at Chignik, each moving in an opposite direction. In 2002 the co-op policy supplanted limited entry fishing with a single fishery-wide season, and in early 2005 an Alaska Supreme court decision shut down the co-op, abruptly reinstating the original system. These policy treatments help us to cleanly separate the co-op's fishery-wide effects from fishery specific time trends. ${ }^{11}$ Third, the skill of the 100 permit holders at Chignik varied substantially. This fact enables us to assess how fishing skill affected the decision to join or remain independent and also how relative skill affected which co-op fishermen actively fished as co-op 'employees'.

Our findings generally confirm theoretical predictions by us and others - that coordinated use of a common pool resource can end the race to extract and enhance rent capture (see, e.g., Wilson, 1990; Scott, 2000). Some of the co-op's gains were realized by consolidating effort among its higher skilled fishermen and by increasing the value of the output, the efficiency channels often emphasized in discussions of fishery reform. ${ }^{12}$ However, the co-op achieved additional gains through channels seldom mentioned in the reform literature: by coordinating on the location and timing of fishing, by sharing information on stock locations and by providing shared infrastructure. ${ }^{13}$ We find no evidence of such behavior by independents. Despite clear evidence of an aggregate rent gain, the lawsuit filed by two independents indicates that some felt disadvantaged by the regime change. This motivates us to derive conditions under which allowing

\footnotetext{
${ }^{10}$ The migratory nature of the species, sockeye salmon, made it possible for the regulator to separate the stock between the two groups of fishermen by opening and closing separate seasons for each. By this sort of separation, one group's harvesting opportunities were unaffected by the actions of the other group. Clearly, such separation is not possible for all common pool resources.

${ }^{11}$ The fact that the treatment "switch" was turned on, and then off, strengthens the case that the change in behavior of the treated fishery between treated and untreated periods is causal (Meyer, 1995, p. 158).

${ }^{12}$ These are key benefits of ITQ reforms, which is the most common type of rights-based system used in the industrialized world (see Grafton et. al. 2000, Hannesson 2004, Leal 2002, Linn 2008, Newell et. al. 2005).

${ }^{13}$ Several authors have identified conditions under which a simple assignment of rights, e.g. shares of an ITQ fishery, will not fully incentivize profit maximizing behavior (Boyce, 1992; Costello and Deacon, 2007). An emerging body of evidence examines the efficiency effects of cooperative management, including the contracting problems therein (Johnson and Libecap, 1982; Ostrom, 1990; Wilson, 1990; Knapp and Hill, 2003; Costello and Deacon, 2007). Others argue that dividing a total catch between two sectors, as when a share is allocated to a cooperative, is likely to be a much simpler negotiating task than allocating unique shares to all individual harvesters (Matulich et al., 2001).
} 
a voluntary co-op to form will be Pareto improving and to see if these conditions were met at Chignik.

In the following section we develop a model of the cooperative-based management regime and derive a number of predictions regarding membership, fishing intensity, efficiency, public input provision, and profitability in each sector. The model also provides conditions describing how the catch must be divided in order to yield a Pareto improvement. Section 3 presents empirical tests of the model's predictions and estimates of the rent gains from allowing the co-op to form. Section 4 describes the court decision that eventually ended the co-op and draws lessons for the implementation of this approach to common pool resource management more generally. It also comments on the practical importance of our results for the ecological and economic state of fisheries.

\section{Model}

The policy we examine grants permit holders the option to either join a profit-sharing cooperative or to remain independent. A fishery-wide total allowable catch (TAC), determined by the regulator, is divided into two portions that are separable across time or space, one for the coop and the other for independents. Under the original policy all license holders fished competitively until the TAC was reached, at which point the entire fishery was closed. This regime, which naturally encourages a race to fish, still applies to the group choosing to remain independent, so their individual success depends on skill and prior investments in racing capital. ${ }^{14}$ Those who join the co-op act under the direction of a central manager who seeks to maximize the co-op's profit. We examine how behavior differs between the two sectors as well as the gains and losses individual fishermen experience when the co-op is allowed to form.

Our model takes as given the size of the stock and the regulator's TAC and focuses on the within-season activities of a fixed number of license holders. It incorporates three features that are present in many actual fisheries: (1) heterogeneity in the skill levels and alternative employment opportunities of individual fishermen; (2) heterogeneity over time and/or space in the unit value of the stock; and (3) the potential for fishermen to gain, collectively, by sharing information, infrastructure or other public inputs. These features allow us to examine three important aspects of the allocation of fishing effort: (1) avoiding redundant capacity and assigning fishing activity to the most efficient fishing units, sometimes referred to as

\footnotetext{
${ }^{14}$ This form of management is common in U.S., Canadian, and European waters.
} 
'rationalization' of effort; (2) coordinating effort over time and space to avoid races for the most valuable portions of the stock; (3) providing efficient levels of public inputs.

Fishing skill is parameterized by the term $\gamma$, which we interpret as the rate at with a fisherman can apply effort. Fisherman $h$ 's total effort is the product of $\gamma_{h}$ and the time $h$ spends fishing, $T_{h}$. We parameterize the opportunity cost of time with $\phi$. If $h$ has an attractive opportunity in another fishery that operates at the same time, or in an entirely different occupation, $\phi_{h}$ will be large.

The unit value of the stock varies over space because it migrates toward a port where fishing vessels and processing facilities are based and the cost per unit effort falls as the stock comes nearer. ${ }^{15}$ We parameterize this by dividing the fishing grounds into two zones and regarding the distance to each as a single value, 0 or $\bar{d}$. These zones are called 'inside' and 'outside', respectively, and distance is normalized so that fishing at an additional unit of distance increases the cost per unit effort by 1 unit. ${ }^{16}$ We assume the stock spends time $\bar{T}$ in each zone.

The cost per unit effort can be reduced by the availability of a public good input, $G$. Examples of $G$ include shared information on stock locations and shared infrastructure. Individual contributions to the public good, denoted $x_{h}$, are costly to contributors and total provision of $G$ is determined by the aggregate amount contributed. Later, we allow for separate provision by two groups of harvesters and specify that the benefits of a public input are restricted to the group that provides it, i.e., it is a club good.

Combining these components and including a common cost per unit effort parameter $\alpha$, fisherman $h$ 's total cost is

$$
c_{h}=\left\{\alpha+d_{h}-G\left(\sum_{h} x_{h}\right)\right\} \gamma_{h} T_{h}+\phi_{h} T_{h}+x_{h} .
$$

The expression in brackets includes all cost components that are proportional to $h$ 's effort. We assume $G(0)=0, G^{\prime}>0, G^{\prime \prime}<0$ and $\alpha+d_{h}-G(\cdot)>0 \forall h$.

Total catch, $Q$, is assumed to be a linearly homogeneous function of aggregate effort, $E$, and the stock, $Z$. The fishing technology is represented by

\footnotetext{
${ }^{15}$ Because the stock migrates along a route, this variability could be characterized as occurring over time.

${ }^{16}$ The decision to fish inside versus outside can be taken literally or as a metaphor for a broader class of gains from coordination. Coordination gains from timing harvest activities, improving catch quality and sharing information are described in the next section.
} 


$$
Q=Z F(E / Z)
$$

where $F^{\prime}>0, F^{\prime \prime}<0, F(0)=0$ and $F(E / Z)<1$. Fig. 1 illustrates the catch technology. Given an available stock, $Z$, applying $E_{T}$ units of effort will yield a catch of $Q_{T}$. If that effort is applied sequentially, with $E_{0}$ units applied first and $E_{T}-E_{0}$ units subsequently, the first 'batch' of effort yields a catch of $Z F\left(E_{0} / Z\right)$ and the second yields a residual catch of $Q_{T}-Q_{0}=Z\left(F\left(E_{T} / Z\right)-F\left(E_{0} / Z\right)\right)$. Concavity of $F(\cdot)$ implies that catch per unit effort for the first application of effort (slope of line $a b$ ) is greater than for the second (slope of line $b c$ ).

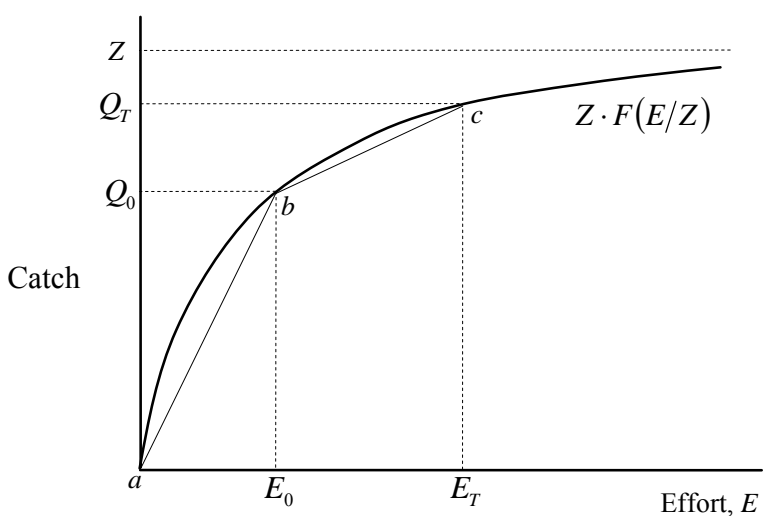

Fig. 1. Catch effort function

In the case we examine the stock migrates toward port and the batches of effort correspond to effort applied in the two distance zones. Individuals who fish outside are the first to apply effort and therefore achieve a higher catch per unit effort than those who fish inside. All those fishing in a given distance zone are assumed to experience the same catch per unit effort. ${ }^{17}$

The regulator's goal is an escapement target of $(1-\beta) Z$, implying that the TAC equals $\beta Z$. Given (2) this implies that total effort must satisfy $E \leq Z F^{-1}(\beta)$. Total effort for a set of fishermen is $\sum_{h} \gamma_{h} T_{h}$ and the regulator meets the TAC by constraining fishing times to satisfy

$$
\sum_{h} \gamma_{h} T_{h} \leq Z F^{-1}(\beta) \equiv \kappa
$$

\footnotetext{
${ }^{17}$ Costello and Deacon (2007) apply similar reasoning to harvesting of a non-migratory stock that inhabits patches at varying distances from port.
} 
Before fishing starts harvesters are allowed to join a co-op that will coordinate its members' effort, with the goal of maximizing total co-op profit. Those not joining choose distance, time spent fishing and public input contributions individually, taking as given the decisions of the regulator and other independents. The sets of independent harvesters and co-op joiners are denoted $I$ (independents) and $J$ (joiners) and their respective numbers are $n(I)$ and $n(J)$. The regulator assigns portions of the stock to each group in proportion to these numbers and in such a way that one group's harvest opportunities are unaffected by the actions of the other group. ${ }^{18}$ The separate stock assignments are denoted $Z_{I}$ and $Z_{J}$, the separate TAC assignments are $\beta Z_{I}$ and $\beta Z_{J}$, and the regulator constrains each group's fishing times according to (3) to meet these TAC assignments. We assume cost parameters are such that each firm is capable of earning positive profit by fishing independently, regardless of the composition of the independent and co-op fleets. ${ }^{19}$ The initial joining decision and subsequent decisions on effort deployment are modeled as a two-stage entry game. Subgame perfect Nash equilibria are identified by backward induction.

\section{Stage 2 choices by the co-op}

The co-op's manager is motivated to maximize total co-op profit and the co-op's total catch is fixed by the regulator. Consequently, the co-op's optimal policy solves the following cost minimization problem:

$$
\min _{d_{i}, T_{i}} \sum_{i \in J ; x_{J}}\left(\alpha+d_{i}-G\left(x_{J}\right)\right) \gamma_{i} T_{i}+\sum_{i \in J} \phi_{i} T_{i}+x_{J}
$$

subject to $d_{i} \in\{0, \bar{d}\}, T_{i} \in[0, \bar{T}]$ for all $i \in J$, and a regulatory constraint on members' fishing times set according to (3). $x_{J}$ is the co-op's expenditure on the public input.

\footnotetext{
${ }^{18}$ The possibility of partitioning a stock in this fashion depends on the behavior of the target species. We examine a migrating species, sockeye salmon. In practice the regulator partitioned the stock between the two harvester groups by specifying different season openings and closures for each. As a consequence the two groups could operate on separate portions of the overall run without interfering with one another. A spatial division may achieve this result for a sedentary species.

${ }^{19}$ This is consistent with the presence of positive license values under purely independent fishing in the fishery we examine empirically.
} 
The co-op's optimal policy is straightforward. ${ }^{20}$ First, it sets $d_{i}=0$ for each member. This is obvious because (4) is non-decreasing in the $d_{i}$ for each member and strictly increasing in $d_{i}$ for any member who spends positive time fishing. Second, the co-op's policy assigns positive harvest times to a subset of members who have low values of the ratio $\phi_{i} / \gamma_{i}$ and limits the number who actually fish so that the co-op's season lasts the entire time fish are available, $\bar{T} \cdot{ }^{21}$ Other co-op members do not fish at all. The intuition for this result is as follows. Since $\phi_{i}$ and $\gamma_{i}$ are $i$ 's cost per unit time and effort per unit time, respectively, the ratio $\phi_{i} / \gamma_{i}$ is $i$ 's cost per unit effort, so it is sensible to concentrate effort among low $\phi_{i} / \gamma_{i}$ members. By slowing the rate of fishing and making its season last as long as possible, the co-op concentrates effort among these efficient members to the greatest extent possible. Third, the co-op's public input provision satisfies

$$
G^{\prime}\left(x_{J}\right) F^{-1}(\beta) Z_{J} \leq 1,
$$

where $x_{J} \geq 0$ and (5) holds with equality if $x_{J}>0$.This is a Samuelson condition for optimal provision of a public good.

These results are summarized as

Proposition 1 The co-op's policy requires that:

(i) All active co-op members fish as close to port as possible;

(ii) Only members with low cost per unit effort $\left(\phi_{i} / \gamma_{i}\right)$ apply effort, these efficient members fish the entire time the season is open, and the season is open for $\bar{T}$ periods, the entire time the stock is available;

(iii) Provision of the public input equates the co-op's aggregate marginal benefit from provision to marginal cost, satisfying a Samuelson efficiency condition.

Proof: See text and the Appendix.

Stage 2 choices by independents

The independent fleet's catch per unit effort at any location $d$ depends on the effort levels and locations of all independents. We denote catch per unit effort

\footnotetext{
${ }^{20}$ The assumption that any co-op member could have earned positive profit from fishing as an independent implies that the co-op's maximal profit is necessarily positive. By joining the co-op, each member avoids any cost associated with fishing outside and benefits from the public input.

${ }^{21}$ See the Appendix.
} 
by $H\left(d ; d_{i}, \gamma_{i}, T_{i}, i \in I, Z_{I}\right)$ and assume each independent takes it as given. ${ }^{22}$ Independent $h$ 's profit when the set $I$ fishes independently is

$$
\pi_{h}=H\left(d_{h} ; d_{i}, \gamma_{i}, T_{i}, i \in I, Z_{I}\right) \gamma_{h} T_{h}-\left(\alpha+d_{h}-G\left(\sum_{i \in I} x_{i}\right)\right) \gamma_{h} T_{h}-\phi_{h} T_{h}-x_{h}
$$

Independent $h$ 's profit is linear in $T_{h}$ and, by assumption, maximal profit is positive. Firm $h$ 's maximal profit is therefore increasing in $T_{h}$. This implies $T_{h}=T_{I}$ for all $h \in I$, i.e., all independents fish the entire time their season is open.

Independent $h$ 's optimal public input contribution satisfies the first-order condition

$$
G^{\prime}\left(\sum_{i \in J} x_{i}\right) \gamma_{h} T_{I} \leq 1
$$

where $x_{h} \geq 0$ and (7) holds with strict equality if $x_{h}>0$. The left-hand and right-hand sides of (7) are $h$ 's private marginal benefit and marginal cost for contributing. Let $i^{*}$ be the independent with the highest $\gamma$ among all independents; the private marginal benefit of contributing is greatest for this independent. Assuming individual fishermens' $\gamma$ parameters are distinct, if $G^{\prime}(0) \gamma_{i^{*}} T_{I}>1$ then the unique Nash equilibrium requires this harvester and only this harvester to make a contribution; $i^{*}$ 's contribution in this case satisfies (7) with equality. ${ }^{23}$ Alternatively, if $G^{\prime}(0) \gamma_{i^{*}} T_{I} \leq 1$ then each independent fisherman's optimal contribution is zero. In either case, it is clear (and unsurprising) that independents under-provide the public input.

\footnotetext{
${ }^{22}$ The number of independents is assumed sufficiently large that each individual ignores the effect of his/her effort level on the group's catch per unit effort.

${ }^{23}$ Given that (7) is satisfied with equality for independent $i^{*}$, the inequality must be strict for all other independents, implying that their optimal contribution is zero. This is a standard free-rider equilibrium.
} 


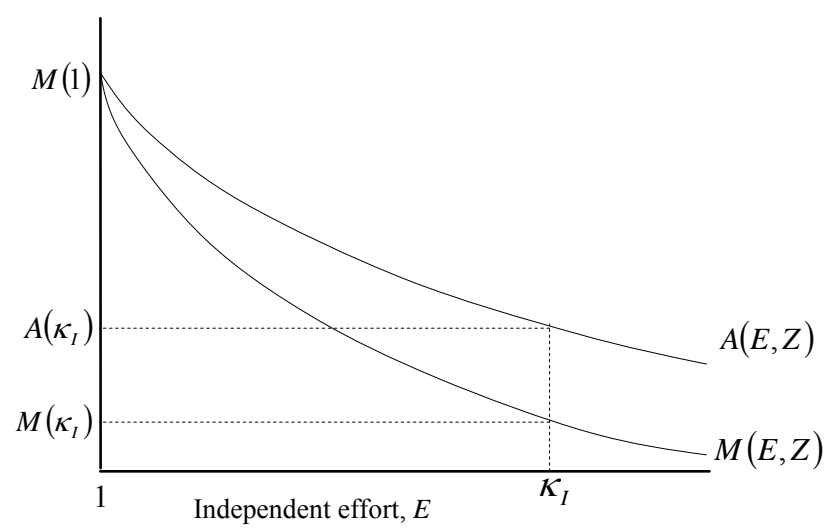

Fig. 2. Independent fisherman $h$ 's catch per unit effort, depending on where other independents fish

The choice of fishing distance can be examined using the marginal and average catcheffort functions, $M(E, Z) \equiv \partial Q / \partial E=F^{\prime}(E / Z)$ and $A(E, Z) \equiv Q / E=F(E / Z) /(E / Z)$. The shapes of theses functions, shown in Fig. 2, are determined by the monotonicity and concavity of $F(\cdot)$. To meet the catch target, the regulator fixes total independent effort according to (3), at a level denoted $\kappa_{I}$. If all independents fish at the same distance, all obtain the same average catch per unit effort, $A\left(\kappa_{I}, Z\right)$, regardless of whether all fish inside or outside. ${ }^{24}$ Suppose independent $h$ chooses to fish inside while all other independents fish outside. In this case $h$ encounters the stock after other independents have fished and obtains the marginal (rather than average) catch per unit effort from $\kappa_{I}$ units of effort, $M\left(\kappa_{I}\right)$. Alternatively, if $h$ fishes outside while all other independents fish inside, $h$ 's catch per unit effort would be $M(1)$ in Fig. 2, the marginal catch from the first unit of effort. ${ }^{25}$

If all independents are fishing outside, any individual who deviates to the inside would find that cost per unit effort falls by $\bar{d}$, but catch per unit effort falls by $A\left(\kappa_{I}\right)-M\left(\kappa_{I}\right)$. If $A\left(\kappa_{I}\right)-M\left(\kappa_{I}\right)>\bar{d}$, which we refer to as Condition (i), then no independent will find it profitable to deviate inside. ${ }^{26}$ If Condition (i) holds, which is more likely when $\bar{d}$ is small, the Nash equilibrium strategy profile in this subgame is unique and requires that all $\kappa_{I}$ units of effort fish outside. Suppose, instead, that all independents are fishing inside. In this case any individual

\footnotetext{
${ }^{24}$ We henceforth suppress the second argument in $A(\cdot)$ and $M(\cdot)$, since it remains unchanged.

${ }^{25}$ Fisherman $h$ 's catch equals $h$ 's catch per unit effort times the effort $h$ applies, $\gamma_{h} T_{I}$. Catches from the same location will therefore differ among fishermen in proportion to their $\gamma$ parameters.

${ }^{26}$ The common cost term $\phi_{h} T_{I}$, which appears in both profit comparisons, has been ignored.
} 
who deviates outside will find that cost per unit effort increases by $\bar{d}$, but catch per unit effort increases by $M(1)-A\left(\kappa_{I}\right)$. If $M(1)-A\left(\kappa_{I}\right)<\bar{d}$, which we refer to as Condition (ii), then no independent will find it profitable to deviate outside. If Condition (ii) holds, which is more likely when $\bar{d}$ is large, a Nash equilibrium in this subgame is unique and requires that all $\kappa_{I}$ units of effort fish inside.

Finally, suppose $A\left(\kappa_{I}\right)-M\left(\kappa_{I}\right) \leq \bar{d} \leq M(1)-A\left(\kappa_{I}\right)$ so neither condition holds. This implies that a Nash equilibrium strategy profile for the second stage subgame cannot have all effort fishing either inside or outside. We illustrate this case in Fig. 3. The horizontal axis now indicates outside effort and the dashed line $A(E)-\bar{d}$ shows outsider profit per unit effort. To characterize Nash equilibrium choices of distance, suppose all independent effort was initially fishing outside and successive units were transferred inside. The first unit transferred inside would earn profit $M\left(\kappa_{I}\right)$, shown by point $c$, which exceeds the profit from fishing outside. Transferring successive effort units inside causes insider profit per unit effort to increase toward point $a$, at which point all effort is fishing inside and profit per unit effort equals $A\left(\kappa_{I}\right)$. The dotdash line labeled 'insider profit' traces out one possible locus of insider profits. ${ }^{27}$ If $\hat{E}$ units of effort fish outside and all others fish inside so all earn equal profit, no one has an incentive to deviate. ${ }^{28}$ Accordingly, a Nash equilibrium strategy profile in this case is described by this division of inside and outside fishing.

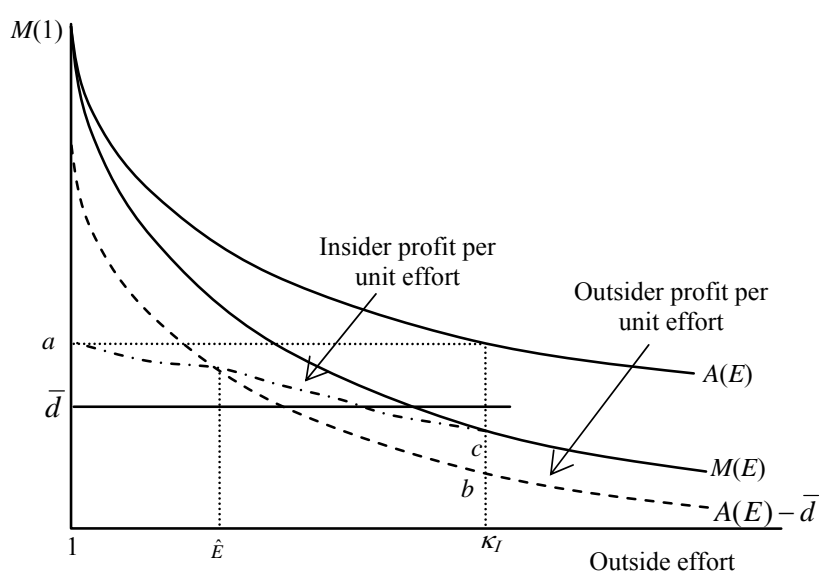

Fig. 3. A NE strategy profile in which some independents fish outside while others fish inside.

\footnotetext{
${ }^{27}$ It can be shown that the dot-dash line is monotone and continuous.

${ }^{28}$ Fig. 2 is drawn so these curves only cross once; we have not excluded the possibility that they cross more than once.
} 
We summarize these results as

Proposition 2 In the subgame involving the independent sector's choice of time spent fishing, public input contributions, and fishing locations, a Nash equilibrium strategy profile requires that:

(i) Each independent harvester fishes the entire time the regulator leaves the independents' season open;

(ii) The independent sector under-provides the public input relative to what is efficient;

(iii) All independents fish outside if $A\left(\kappa_{I}\right)-M\left(\kappa_{I}\right)>\bar{d}$, fish inside if $M(1)-A\left(\kappa_{I}\right)<\bar{d}$ and are split between fishing inside and fishing outside if $A\left(\kappa_{I}\right)-M\left(\kappa_{I}\right) \leq \bar{d} \leq M(1)-A\left(\kappa_{I}\right)$.

Proof: See Figs. 2 and 3 and the preceding discussion.

We also note that the TAC constraint (3) and the regulator's stock assignment, $Z_{I}=Z n(I) / n(K)$, imply that the independent sector's season length equals

$$
T_{I}=\frac{Z F^{-1}(\beta) / n(K)}{\sum_{i \in I} \gamma_{i} / n(I)}
$$

and is therefore inversely proportional to the group's average skill, a result that will become useful later.

\section{The Stage 1 decision of whether or not to join}

We adopt the convention that fishermen are indexed in increasing order of their $\gamma$ terms, so low skill fishermen have low index numbers. To obtain a clear identification on the attributes of co-op joiners, we assume that high skill harvesters (high $\gamma$ ) have low cost per unit effort (low $\phi / \gamma$ ). This will be true if the $\phi$ terms are constant, if $\phi$ and $\gamma$ are inversely ordered, or if $\phi$ does not increase more than proportionately as $\gamma$ increases.

We start by examining the second stage profit shares of successive co-ops in which new members are added in order of their $\gamma$ parameters and demonstrate that larger co-ops (formed in this fashion) necessarily have higher profit per member. Writing out the co-op's profit share equation and incorporating its optimal policy choices and the regulator's TAC assignment yields

$$
\pi_{J}(J)=\frac{Z}{n(K)}\left(\beta-\alpha F^{-1}(\beta)\right)+\frac{1}{n(J)}\left\{G\left(x_{J}^{*}\right) F^{-1}(\beta) \frac{Z n(J)}{n(K)}-x_{J}^{*}\right\}-\frac{1}{n(J)} \sum_{i \in J_{\min }} \phi_{i} \bar{T}
$$


where $J_{\min }$ indicates the set of co-op members selected to fish and $x_{J}^{*}$ is the co-op's optimal public input contribution. The rhs consists of three components. The first is catch per member minus the common cost term involving $a$. Given the TAC allocation formula, this does not depend on co-op size. The second component is the co-op's maximal net public good benefit per member. As shown in the Appendix, it necessarily is increasing in $n(J)$. The third component is the opportunity cost of time spent fishing divided by the number of co-op members; it decreases with co-op size for the following reason. If a new member is added the TAC allocation rule causes a proportionate increase in the co-op's effort, so effort per member remains unchanged. Consequently, the effect of a new member on the third component in (9) coincides with the new member's effect on the co-op's average time cost per unit effort. Given the order in which members are added, the new member's time cost per unit effort $(\phi / \gamma)$ is necessarily less than that of existing members. Therefore, the new member will be designated to fish and the co-op's average time cost per unit effort falls.

Taken together these results imply that co-op profit per member increases with co-op size, as illustrated by the upward sloping line $\pi_{C}(\gamma)$ in Fig. $4 .{ }^{29}$ The positive co-op profit shown for the lowest skill level follows from the assumption that all fishermen could earn positive profit by fishing independently, plus the fact that (i) a one member co-op would receive its own TAC allocation and thereby avoid fishing outside and (ii) its allocation exceeds what the least skilled harvester would catch as an independent. This reasoning also implies that a 1 member co-op's profit exceeds what the same fisherman could earn by fishing independently with all other harvesters, a result that is useful shortly.

\footnotetext{
${ }^{29}$ This solid line is a smooth curve connecting a set of discrete points indicating the per member profits for co-ops of different sizes.
} 


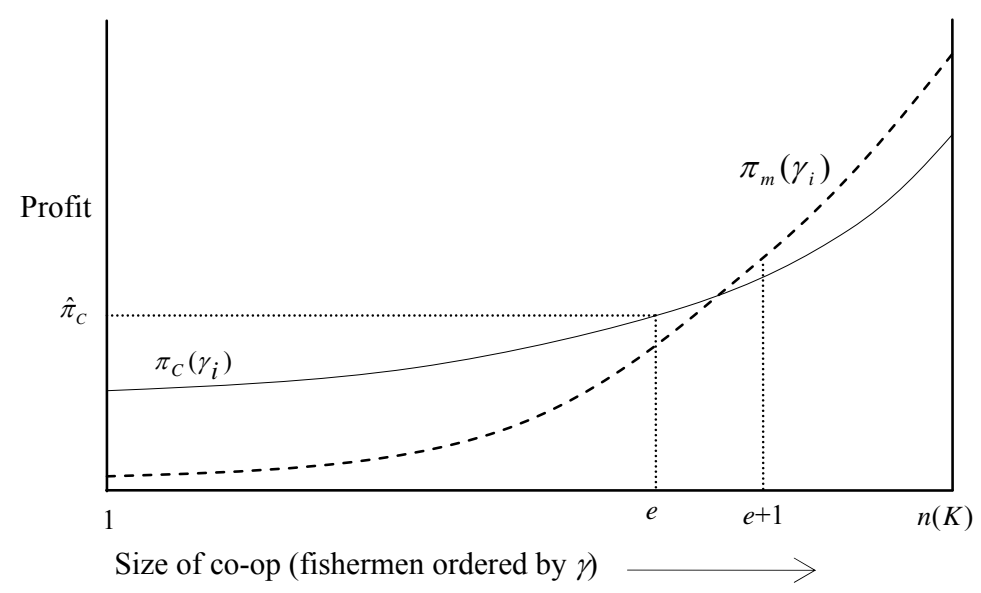

Fig. 4. Equilibrium co-op size

Next, we examine the profit of the marginal (least profitable) co-op member in a sequence of independent fleets formed by successively adding lower skilled harvesters and demonstrate that the marginal independent's profit necessarily falls as the size of the independent fleet grows. To simplify, we assume the independent fleet's equilibrium public input provision is 0 , which is always approximately true. We also make use of the convention $G(0)=0$ and the fact that catch per unit effort equals $\beta / F^{-1}(\beta)$ due to the TAC constraint. Incorporating these simplifications in (6), independent harvester $h$ 's profit in the case where all independents fish outside is

which we write as

$$
\begin{gathered}
\pi_{h}(I)=\left\{\left(\frac{\beta}{F^{-1}(\beta)}-\alpha-\bar{d}\right) \gamma_{h}-\phi_{h}\right\} T_{I}, \\
\pi_{h}(I)=\left\{\frac{\beta}{F^{-1}(\beta)}-\alpha-\bar{d}-\frac{\phi_{h}}{\gamma_{h}}\right\} \gamma_{h} T_{I} .
\end{gathered}
$$

Our earlier assumption implies that $\phi / \gamma$ falls as $\gamma$ increases, so independents with higher skill parameters have higher profits. The marginal (least profitable) independent in any group is therefore the one with the lowest $\gamma$ and forming a sequence of independent fleets by successively adding lower skill fishermen causes marginal profit to decline. The same conclusion applies in the case where all independents fish inside because $h$ 's profit in this instance is found by replacing the constant $\bar{d}$ in (10) by zero. This result also extends to the case where some independents fish inside and others fish outside because equilibrium in the second stage requires 
that each independent earns the same profit per unit effort at either location. This implies that the inside vs. outside differential in catch per unit effort exactly matches the differential in cost per unit effort, $\bar{d}$, so once again independents with higher skill parameters have higher profits. ${ }^{30}$

The dashed line $\pi_{m}\left(\gamma_{i}\right)$ in Fig. 4 illustrates the marginal profit in a group of independent fishermen who have efficiency parameters greater than or equal to a given level $\gamma_{t}$. The left vertical intercept of $\pi_{m}\left(\gamma_{i}\right)$ lies below the $\pi_{C}\left(\gamma_{i}\right)$ intercept because, as explained earlier, a 1 member co-op's profit exceeds what the same fisherman could earn by fishing independently with all other harvesters. The right vertical intercept of $\pi_{m}\left(\gamma_{i}\right)$ is shown to lie above the corresponding intercept for the co-op, indicating that the highest skilled fisherman could earn more by fishing as a lone independent than by joining an all-inclusive co-op, but this is not the only possibility. If both conditions on intercepts are met then $\pi_{m}\left(\gamma_{i}\right)$ must $\operatorname{cross} \pi_{C}\left(\gamma_{i}\right)$ from below at least once.

Such a crossing point identifies a threshold skill level that separates co-op joiners from independents. In Fig. 4 the threshold is index value $e$, referring to a fisherman with skill level $\gamma_{e}$. If all harvesters with skill less than or equal to $\gamma_{e}$ are in the co-op then: (i) all those in the co-op earn $\pi_{C}\left(\gamma_{e}\right)$, which exceeds that they would earn by fishing independently, and (ii) all those who fish independently earn more than they would in the co-op since $\pi_{m}\left(\gamma_{i}\right)>\pi_{C}\left(\gamma_{e}\right) \forall i>e \cdot{ }^{31}$ This allocation of fishermen to groups, together with Nash equilibrium strategy profiles in stage 2 , is therefore a subgame perfect Nash equilibrium. If $\pi_{m}\left(\gamma_{i}\right)$ lies entirely below $\pi_{C}\left(\gamma_{i}\right)$, the allocation in which all harvesters join the co-op is the only Nash equilibrium. If the two curves cross more than once, there is an equilibrium for each occasion where $\pi_{m}\left(\gamma_{i}\right)$ crosses $\pi_{C}\left(\gamma_{i}\right)$ from below. The generic Stage 1 prediction, that high $\gamma$ fishermen choose to fish independently, is not surprising; by definition, highliners compete most successfully in the race to fish and joining the co-op would necessitate sharing their harvest profits with less skilled fishermen. ${ }^{32}$

\footnotetext{
${ }^{30}$ The $\beta / F^{-1}(\beta)-\alpha-\bar{d}$ term is replaced by one of two expressions in this case, depending on whether the individual involved fishes inside or outside, but these two expressions take on the same value.

${ }^{31}$ We assume a fisherman joins the co-op if profits from the two choices are equal. The condition stated in the text is equivalent to the internal and external stability conditions for cartel formation developed by d' Aspremont, et al. (1983).

${ }^{32}$ We have not demonstrated that $\pi_{m}\left(\gamma_{i}\right)$ increases monotonically. As the independent fleet's average skill level increases the season length falls, which works against the profit increase from greater skill.
} 
Key results on the joining decision are summarized as:

Proposition 3 Under our assumption on the relationship between effort rate and time cost parameters, a subgame perfect Nash equilibrium strategy profile has the following properties:

(i) The group choosing to fish independently consists of highliners; more precisely, all independents have skill levels greater than any co-op member;

(ii) The choices of distance, fishing time and public input contributions are described by Propositions 1 and 2.

\section{Characterizing Pareto-improving catch allocations}

The above discussion characterizes the membership and economic behavior of heterogeneous fishermen composing the two fleets. Here we identify conditions under which allowing formation of the self-selected cooperative is Pareto improving.

The answer hinges on the allocation of catch between the two sectors. We have assumed thus far that the regulator assigns catch in proportion to membership: $Z_{J}=Z n(J) / n(K)$. To explore this issue more completely, we generalize this notion to allow for disproportionate assignments: $Z_{J}=Z \theta n(J) / n(K)$ where the scalar $\theta$ controls the proportional assignment to the cooperative sector. For example, if $\theta=0.9$ then the cooperative is assigned a stock allocation that provides nine-tenths of a per capita share for each co-op joiner. Intuitively, it would seem that cooperative members would be advantaged and independents disadvantaged by larger values of $\theta$, but the endogeneity of self-selected membership may blur this intuition. We start by deriving the profit for an arbitrary fisherman, $h$, in a 'completely independent fishery', a term we use to refer to the counterfactual situation where no co-op is allowed to form. We then compare this profit to what $h$ would earn when the cooperative is allowed to form. Naturally, we simultaneously solve for whether fisherman $h$ fishes independently or as a member of the cooperative fleet.

In a completely independent fishery (i.e. if the co-op were not allowed for form), $h$ would earn the following profit from independent fishing:

$$
\tilde{\pi}_{h}=\left(\frac{\beta}{F^{-1}(\beta)}-\alpha-\bar{d}-\frac{\phi_{h}}{\gamma_{h}}\right) \gamma_{h} \widetilde{T},
$$

where $\widetilde{T}$ is the season length in the absence of a cooperative, given by: $\widetilde{T}=Z F^{-1}(\beta) / \sum_{\forall i} \gamma_{i}$.

When the voluntary cooperative is allowed to form, $h$ 's profit depends on whether he/she decides to join or to fish independently. Suppose $h$ chooses to fish in the independent fleet. The resulting profit is: 


$$
\pi_{h}=\left(\frac{\beta}{F^{-1}(\beta)}-\alpha-\bar{d}-\frac{\phi_{h}}{\gamma_{h}}\right) \gamma_{h} T_{I},
$$

Here, $T_{I}$ is the season length for the independent fleet, given by $T_{I}=Z_{I} F^{-1}(\beta) / \sum_{i \in I} \gamma_{i}$. The stock assignment $Z_{I}$ depends on the allocation rule as follows: $Z_{I}=\left((1-\theta)+\theta \frac{n(I)}{n(K)}\right) Z$. Fisherman $h$ gains from the co-op's formation if $\tilde{\pi}_{h}<\pi_{h}$, and loses if $\tilde{\pi}_{h}>\pi_{h}$, which clearly depends on the allocation parameter $\theta$. Setting the right-hand sides of equations (11) and (12) equal, we can solve for the critical parameter value, $\theta_{c}$, that yields the same profit for $h$ regardless of whether the co-op forms:

$$
\theta_{c}=\frac{\sum_{i \in J} \gamma_{i} / n(J)}{\sum_{\forall i} \gamma_{i} / n(K)}
$$

where $J$ is the set who would join. ${ }^{33}$ The rhs of (13) is the ratio of average skill for those who would join to the average skill of all fishermen. By Proposition 3, joiners have below-average skill, so $\theta_{c}<1$. Those who would choose to fish as independents are disadvantaged by allowing the co-op to form if $\theta>\theta_{c}$ and they are advantaged if $\theta<\theta_{c}$.

Next, consider the fate of those who opt to join the cooperative if it is allowed to form. Proposition 3 indicates that these individuals are apt to be the lower skilled members of the fleet. Because they coordinate on fishing location and public goods provision (both of which lower costs) their calculus is somewhat different, but it still hinges on how $\theta$ compares to $\theta_{c}$.

If $\theta>\theta_{c}$, the most skilled members of the cooperative are actually disadvantaged by the fact that it forms. Consider the most highly skilled joiner. In the limit, if the number of fishermen is large this individual earns the same profit as the least skilled independent. We established above that all independents are strictly worse off in the presence of the cooperative when $\theta>\theta_{c}$, so the same is true for the highest skill joiner.

\footnotetext{
${ }^{33}$ In a situation where all are fishing the same amount of time per season, as was the case with independent fishing before the co-op was allowed to form, this ratio would equal the ratio of average catches for co-op joiners to the average catch for the entire fleet. It follows that the critical parameter $\theta_{c}$ can be estimated from information on average catch shares of joiners and independents in a pre-co-op period.
} 
We next show that if $\theta=\theta_{c}$, a cooperative still forms and all who join are made better off by the opportunity to join. A sufficient condition for the formation of a cooperative is that the lowest-skill fisherman can earn higher profit by forming a one-person cooperative than by fishing in a completely independent fishery. Revenue in the two situations is the same when $\theta=\theta_{c}$ because a one person cooperative's catch allocation equals what the individual would have caught by completely independent fishing. Cost for the one person cooperative is lower than with independent fishing, however, because the cooperative coordinates on fishing location; so this individual would benefit by forming a one-person co-op. How does the highest skill joiner in a multi-person co-op fare? Given the decision to join, this person's profit as a coop member is at least as great as what he/she could have earned by opting into the independent fleet. In turn, since $\theta=\theta_{c}$ the profit that would have been earned by choosing to fish as an independent equals what this individual would have earned in a completely independent fishery. Thus, all joiners are at least weakly advantaged by the ability to join a cooperative.

Finally, if $\theta<\theta_{c}$ a cooperative may or may not form. Clearly, if $\theta$ is sufficiently near zero the loss from a low catch allocation more than offsets the gains from coordination for a coop of any size, so no co-op will form. Let $\theta_{L}<\theta_{c}$ be the lowest value of $\theta$ for which a cooperative of some size will form. Then for $\theta$ values in the interval $\theta_{L} \leq \theta<\theta_{c}$ a cooperative forms and all fishermen, including independents and joiners, benefit from its formation. To see this, first note that if the independent fleet contains $N(I)$ fishers, then even the least skilled of these individuals is advantaged by co-op's formation because an allocation satisfying $\theta<\theta_{c}$ advantages those who opt into the independent fleet. Next, consider the highest skilled joiner. Given the decision to join, the individual's co-op profit necessarily exceeds what he/she could have earned by opting into the independent fleet. This potential independent fleet profit, in turn, necessarily exceeds what he/she would have earned in a completely independent fishery because $\theta<\theta_{c}$. Therefore the highest skilled joiner is better off from the co-op's formation. All lower-skilled joiners earn the same profit as the highest skilled joiner and would have earned less in a completely independent fishery, so they are all advantaged as well. We summarize all of these findings in the following proposition:

Proposition 4 The formation of a self-selected cooperative has the following distributional consequences: 
(i) If $\theta_{L} \leq \theta \leq \theta_{c}$ the institutional design is Pareto improving - fishermen of all skill levels are made weakly better off by allowing the cooperative to form.

(ii) If $\theta>\theta_{c}$ the institutional design is not Pareto improving - all would-be independents and some would-be cooperative fishermen are made worse off by allowing the cooperative to form.

(iii) If $\theta<\theta_{L}$ then no cooperative forms.

\section{Empirical Evidence}

We test the model's predictions with data from the Chignik sockeye salmon fishery and neighboring fisheries. Chignik is one of Alaska's oldest commercial salmon fisheries, dating to the 1880 s. Prior to 2002 approximately 100 independent purse seine permit holders competed for a share of a fishery-wide limit on allowed catch, which was enforced by closing the season when the target was met. ${ }^{34}$ In 2002 the Alaska Board of Fisheries approved a request by a group of permit holders to form annual cooperatives for voluntary joiners and this arrangement continued through 2004. ${ }^{35}$ The number of fishermen who joined ranged from 77 in 2002 and 2003 to 87 in 2004, with the total number of permits equaling 100 throughout the period. Shortly before the 2005 fishing season, the Alaska Supreme Court shut down the co-op ruling that it violated an Alaska law prohibiting permit holders who did not actively fish from accruing fishery profits. ${ }^{36}$ This history generated three distinct periods that we exploit in our empirical models - the years before the co-op, the co-op years, and the years after the co-op was shut down. The fact that the co-op treatment "switch" was turned on, and then off, helps us isolate the casual effects of the cooperative from fishery specific time trends (Meyer 1995, p. 158), and it helps eliminate serial correlation in our panel regression models (Bertrand et. al. 2004, p. 251).

\footnotetext{
${ }^{34}$ Purse seine fishing uses a large net that cinches from the bottom to prevent schools of fish from escaping. The Appendix shows maps of the Chignik fishing area.

${ }^{35}$ The co-op's proposal explained the motivation for forming the cooperative as follows: "The current fishing fleet is overcapitalized and the competitive harvest system does not allow for real improvements in produc[t] quality or flexibility in competing with farmed salmon" (Grunert v. State 2005, p. 927).

${ }^{36}$ A constrained version of the co-op was allowed to operate during 2005 . The constraint required all co-op members to spend time at sea aboard fishing vessels (Stichert 2007). Because our model implies that this requirement eliminated the main efficiency gains of the co-op, we consider 2004 to be the final year of coop operation.
} 
The model in the preceding section essentially mirrors the fishery's key physical attributes and its actual mode of operation. Regarding physical attributes, sockeye salmon migrate towards only one river in the Chignik system (Chignik R.) and are "funneled" toward that river as the migration extends from open ocean, through Chignik Bay, into Chignik Lagoon, and finally into Chignik River. Processing facilities are located near the destination and the stock becomes more concentrated as it migrates. This generates a tension between the individual incentive to fish outside to contact the stock before others do, and the collective efficiency of harvesting inside near the stock's ultimate destination.

Regarding the mode of operation, the co-op was allocated a share of the total allowable catch (TAC) each year to harvest as it saw fit, with the remainder designated for traditional, competitive harvest by the independent sector. Each co-op joiner signed a 1-year contract before fishing began, agreeing that the cooperative would manage his/her fishing effort for the coming season. The two sectors fished at different times, determined by the regulator, and each sector's season was closed when its TAC share was reached. Each year the co-op's TAC share was determined by the following rule: (i) if less than 85 percent of permit holders joined, the co-op received an allocation equal to nine-tenths of a per capita share for each joiner; and (ii) if 85 percent or more of permit holders joined, the co-op received a full per capita share for each joiner. In terms of the model, these two allocations correspond to $\theta=0.9$ and $\theta=1.0$, respectively. Further, there is significant variation in fishermen's skill levels as measured by share of catch history in years prior to the co-op, indicating the potential for an interior solution where some elect to join the cooperative while others remain independent.

Two features not specifically addressed by our model imply that the co-op's formation could affect price. The first is the presence of monopsony power in Chignik under traditional, non-cooperative fishing - with 100 fishermen, and only one or two processors in the period we study. It is widely believed that processors extract most of the rents from negotiation with independent fishermen; presumably, a coordinated harvester group could wield its own market power. The second is a potential price premium for higher quality product; indeed, the possibility of exercising greater care in harvesting in order to deliver a higher quality product was prominent in initial discussions on forming a co-op. Both considerations indicate that the co-op's formation might lead to higher prices to co-op fishermen. ${ }^{37}$

\footnotetext{
${ }^{37}$ We chose not to incorporate the market power feature explicitly in the model, in part because its effect seems obvious and in part because this seems specific to Chignik and not a feature of common pool resources more generally. The co-op's incentive to coordinate to guarantee higher product quality is similar to its incentive to provide club goods, and in that sense is consistent with our model. The difference is that enhanced product quality raises price, while we treat the effect of club goods as decreasing costs.
} 


\section{Allocation of Fishing Effort}

Perhaps the most compelling reason to form a cooperative in Chignik was to reduce the number of vessels actually fishing (Prop.1.ii), in order to catch its TAC allocation (which depended on membership) more efficiently. Thus, we expect the proportion of permits actually fished to decline during 2002-2004. Figure 5 compares the proportion of permits actively fished in Chignik to the proportion fished across five adjacent purse seine fisheries for years before, during and after the co-op. ${ }^{38}$ As the figure shows, the proportion of permits actively fished in Chignik fell from 0.94 in 2001 to 0.41 in 2002 when the co-op first operated, and then increased after the co-op was effectively dissolved in $2005 .{ }^{39}$ The darkest bars show the difference between Chignik and the average across the control-group fisheries. This difference was strictly positive before and after the co-op years, but approximately zero during 2002-2004.

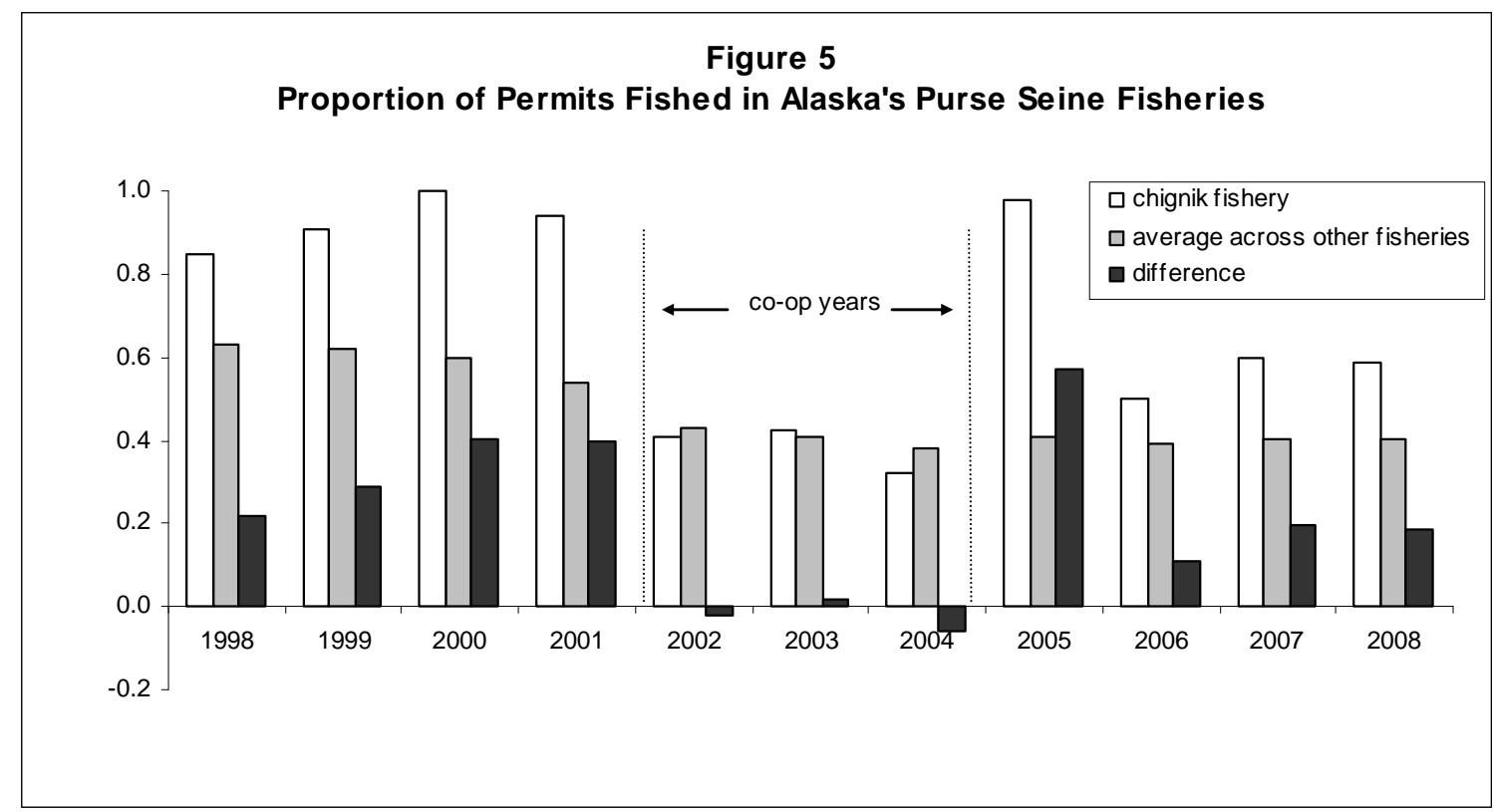

\footnotetext{
${ }^{38}$ The adjacent fisheries are Alaska Peninsula, Cook Inlet, Kodiak, Prince William Sound, and Southeast Alaska.

${ }^{39}$ The spike up to 0.98 in 2005 is worth explaining. In early 2005 , shortly before the start of the fishing season and after the co-op was already formed for the 2005 harvest, the Alaska Supreme Court ruled that the co-op violated an Alaska law prohibiting permit holders who did not actively fish from accruing profits. The state's remedy for the 2005 season was to allow the co-op to fish but to require that all co-op members actively fish for a small part of the season. In 2006, the co-op was entirely dissolved. We discuss the Court decision in more detail later.
} 
A complementary panel regression demonstrates that the visual evidence of the co-op effect is robust to additional controls (Table 1). The panel regression employs 66 fishery-year observations, from 6 fisheries over 11 years (1998-2008). This time span allows four years of data before and after the co-op was active. The regression includes fishery fixed effects, as well as year fixed effects to control for annual variation in factors such as the prices of fuel and farmraised salmon. We also control for the fishery-wide TAC. The result indicates that the co-op policy reduced the proportion of permits fished by nearly 0.27 . The direction of the effect, a reduction, is consistent with expectations and the coefficient estimate is economically and statistically significant. ${ }^{40}$ The result is particularly striking because it pertains to consolidation across the entire fishery. Consistent with our theory, annual Chignik Area management reports indicate that almost all of the consolidation occurred within the co-op; during 2002-2004 the proportion of permits actively fished was $0.25-0.28$ for the co-op and $0.92-1.0$ for independents. ${ }^{41}$

Table 1

Panel Regression on the Proportion of Active Permits

\begin{tabular}{lc}
\hline $\begin{array}{l}\text { Independent } \\
\text { Variables }\end{array}$ & $\begin{array}{c}\text { Y } \\
\text { permits fished } \\
\text { peroportion of }\end{array}$ \\
\hline Constant & $0.329^{*}$ \\
Co-op Policy & $-0.267^{*}$ \\
t-statistic & $(3.69)$ \\
Fishery-Wide TAC & $1.19 \mathrm{e}-07$ \\
Fixed Effects & $(0.29)$ \\
\hline Year Dummies & $\begin{array}{l}\text { Included } \\
\text { Fishery Dummies }\end{array}$ \\
Observations & Included \\
Adjusted R & 66 \\
\hline
\end{tabular}

Notes: (1) * Significant at 0.05 level for a one-tailed t-test. (2) Year dummies span 1998-2008. (3) The 5 control fisheries are the nearby purse seine fisheries: Alaska Peninsula, Cook Inlet, Kodiak, Prince William Sound, and Southeast.

(4) Data are available at: http://www.cfec.state.ak.us/research/salmon/salpmt98_07.pdf and http://www.cfec.state.ak.us/research/salmon/salpmt99_08.pdf.

${ }^{40}$ To correct for possible serial correlation of errors within each fishery we conduct a robustness check recommended by Bertrand et. al. (2004). We collapse the data into averages for each fishery during three time periods - before, during, and after the co-op years. We next run a panel regression using the 18 observations ( 6 fisheries and 3 time periods) and include fishery and time period fixed effects along with the average fishery-wide TAC. This generates consistent standard error estimates (Bertrand et. al. 2004). In our case, the coefficient on Co-op Policy for the collapsed data is -0.271 with a t-statistic of 3.81 .

${ }^{41}$ Members who fished on behalf of the co-op were paid salaries to compensate for their costs. All co-op members were then paid equal shares of the profit remaining after these salaries and other co-op costs were deducted; Knapp and Hill (2003). 
The model further predicts that the co-op will coordinate on the location of harvest in order to reduce costs. Because the co-op secures a guaranteed allocation of catch, co-op harvesters should wait until fish migrate inside, at which time the harvest will be more efficiently executed (Prop. 1.i). In contrast, some or all of the independent sector's harvest is expected to take place 'outside' (Prop. 2.iii). We use data on the spatial location of catch to test these propositions in two different ways. First, we examine fishery-wide annual time-series data to see how the proportion of sockeye caught inside deviated during 2002-2004 from longer annual time trends. We then use within-fishery cross-section data to assess how the proportion of 'inside' catch differed between co-op and independent fishermen during 2002-2004. Our measure of location is the annual proportion caught in Chignik Lagoon (see Fig. A2), the 'inside' location.

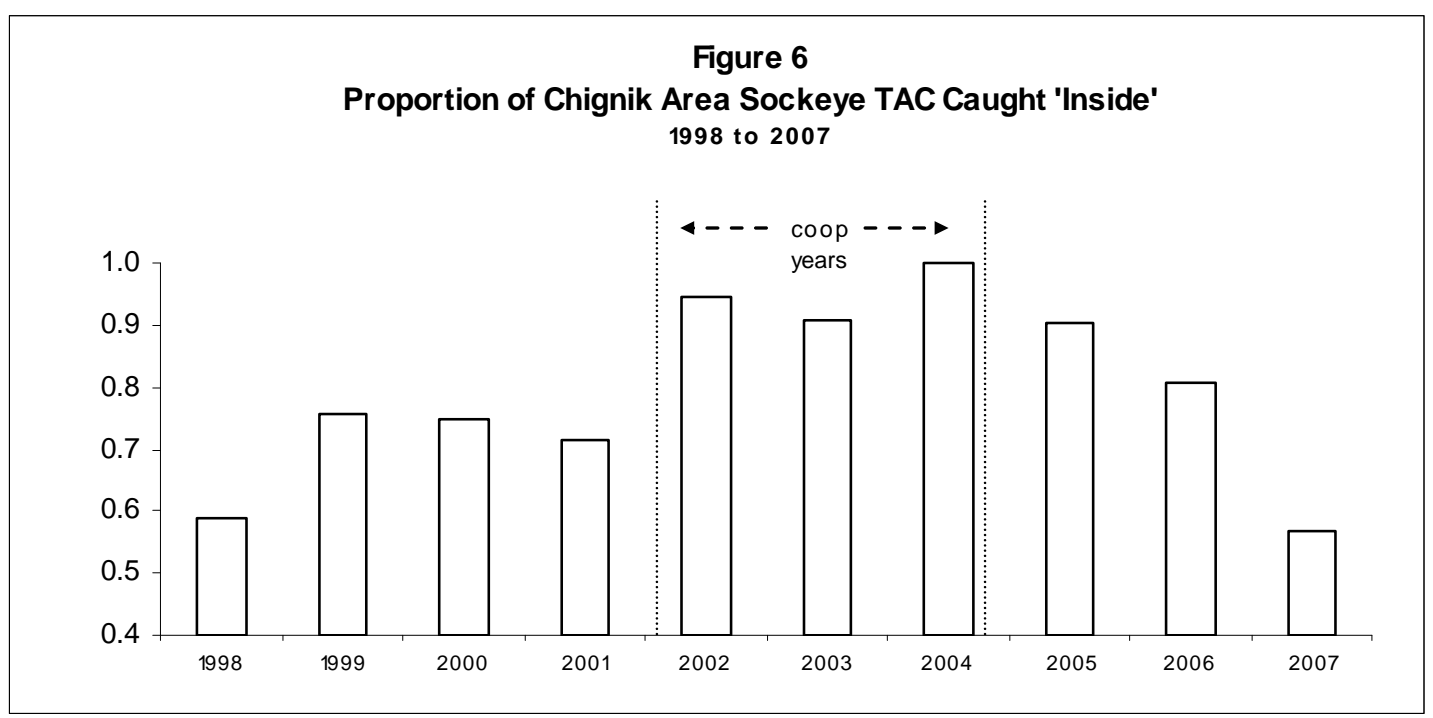

Figure 6 shows the fishery-wide proportion of sockeye caught 'inside' over a 10 year period that includes 2002-2004, the co-op's years of operation, and indicates that the proportion caught 'inside' peaked during the co-op years. The time-series regression model in Column 1 of Table 2 uses annual data on the inside catch proportion for 1970-2007, the entire period for which data are available. It accounts for the cyclical nature of the time-series data by including a $4^{\text {th }}$ order polynomial time trend and controls for variation in harvest by including a $4^{\text {th }}$-order polynomial in the annual allowed catch. Allowing the cooperative to form apparently increased the proportion caught inside by 0.27 , which presumably reduced costs. Note that this proportion applies to the entire fishery, including both co-op fishermen and independents. 
Table 2

Time-Series Regression Analysis of Inside Catch and Season Length

\begin{tabular}{|c|c|c|}
\hline $\begin{array}{l}\text { Independent } \\
\text { variables }\end{array}$ & $\begin{array}{c}\text { (1) } \\
Y=\text { proportion of } \\
\text { catch from inside }\end{array}$ & $\begin{array}{c}\text { (2) } \\
Y=\text { number of } \\
\text { days fished }\end{array}$ \\
\hline Constant & $0.773 *$ & 471.13 \\
\hline $\begin{array}{l}\text { Co-op Policy } \\
\text { t-statistic }\end{array}$ & $\begin{array}{l}0.267^{*} \\
(3.48)\end{array}$ & $\begin{array}{l}32.16^{*} \\
(3.66)\end{array}$ \\
\hline $\begin{array}{l}\text { Fishery-Wide TAC } \\
\text { Fishery-Wide TAC } \\
\text { Fishery-Wide TAC }^{3} \\
\text { Fishery-Wide TAC }\end{array}$ & $\begin{array}{l}4.63 e-07 \\
-1.66 e-07 \\
-4.69 e-20 \\
-2.07 e-07\end{array}$ & $\begin{array}{c}0.0004 \\
-3.14 \mathrm{e}-10 \\
1.02 \mathrm{e}-16 \\
-1.17 \mathrm{e}-23\end{array}$ \\
\hline $\begin{array}{l}\text { Year } \\
\text { Year }^{2} \\
\text { Year }^{3} \\
\text { Year }^{4}\end{array}$ & $\begin{array}{c}0.039 \\
-0.004 \\
0.0008 \\
-2.07 \mathrm{e}-07\end{array}$ & $\begin{array}{c}-106.93^{*} \\
7.107^{*} \\
0.021^{*} \\
0.0004\end{array}$ \\
\hline $\begin{array}{l}\text { Observations } \\
\text { F-statistic } \\
\text { Adjusted } \mathrm{R}^{2}\end{array}$ & $\begin{array}{c}38 \\
6.14 \\
0.664\end{array}$ & $\begin{array}{c}26 \\
1.987 \\
0.528\end{array}$ \\
\hline
\end{tabular}

Notes: (1) * Significant at 0.05 level for a one-tailed t-test (2) The data used here come from Chignik area annual management reports. Column 1 uses available data for 1970-2007. Column 2 uses available data for 1980-2006. We lack data on season length prior to 1980 and the 2007 data are not yet published.

Table 3 compares the location choices of co-op and independent fleets during 2002-2004. As the model predicts, the co-op harvested its entire allocation inside Chignik Lagoon in each year. ${ }^{42}$ By comparison, the independent fleet harvested from both inside and outside in 2002 and 2003, which is consistent with the possibility of a mixed equilibrium. During 2004 when there were only 13 independents, all independent harvest took place inside the lagoon.

42 The following account from a co-op founder makes clear that fishing inside was a conscious operating policy: "We had originally planned to employ a couple of large ... seiners to fish out on the capes [outside], but we realized that the extra running time would increase costs and reduce product quality. Harvesting in the close proximity and concentrated harvest area of the Chignik Lagoon [inside] was simply the most efficient and quality conscious method to pursue." (Ross 2002a). 
Table 3

Proportion of Sockeye Caught Inside by Co-op and Independent Fleets

(on days reserved exclusively for one of the two fleets)

\begin{tabular}{lcc}
\hline & Cooperative fleet & Independent fleet \\
\hline $\mathbf{2 0 0 2}$ & & \\
Number of sockeye harvested & 576,757 & 162,979 \\
Proportion caught inside & 1.00 & 0.82 \\
$\mathbf{2 0 0 3}$ & & \\
Number of sockeye harvested & 757,974 & 334,330 \\
Proportion caught inside & 1.00 & 0.79 \\
$\mathbf{2 0 0 4}$ & & \\
Number of sockeye harvested & 541,400 & 61,446 \\
Proportion caught inside & 1.00 & 1.00 \\
\hline
\end{tabular}

The model also predicts that the co-op's policy will result in a longer fishing season. Prop.1.ii indicates that the cooperative's allocation will be harvested by a subset of its most efficient members. In order to make maximal use of its most efficient harvesters the co-op limits the number of members who actually fish, which slows the rate of fishing and lengthens its season. By contrast, all independents are predicted to fish each day their season is open, causing the regulator to shorten the season in order to meet the TAC constraint.

We test the season length prediction using time-series data for Chignik, employing the same strategy used to examine the proportion of catch from inside. Column 2 of Table 2 uses annual data from the available years, 1980-2006, on the total number of days sockeye salmon fishing occurred at Chignik. The regression estimates indicate that, on average, the presence of the co-op lengthened the season by 32 days, a 48 percent increase in season length from the long run average of 66 days in non co-op years. ${ }^{43}$

We noted earlier the co-op's potential to raise price by delivering higher quality fish or by exercising increased market power in negotiations with processors. We cannot separate these two effects, but we can test for a price increase using a panel-regression model with the same controls as Table 1. The results (Table 4) indicate that formation of the co-op was accompanied by an average price increase of $\$ 0.21$ per pound in the Chignik fishery (in 2008 dollars). This represents a 27.6 percent increase from the Chignik average of $\$ 0.76$ outside of the co-op years. ${ }^{44}$

\footnotetext{
${ }^{43}$ Our theory predicts that the co-op's practice of fishing only a small fraction of its permits will necessarily result in longer season lengths. The regulator's policy of splitting the season into separate openings could also increase season lengths.

${ }^{44}$ The price data are inflation adjusted and are in 2008 dollars. As before we estimated a version of the regression in Table 4 by collapsing the data into averages for each fishery during three time periods -
} 
Note that this is a lower-bound estimate of any price premium the co-op achieved because nearly one-third of the sockeye caught at Chignik were harvested by independents during 2002-2004. ${ }^{45}$

\begin{tabular}{ll}
$\begin{array}{l}\text { Table } 4 \\
\text { Panel Regression of Gross } \\
\text { (in } 2008 \text { dollars) }\end{array}$ & \\
\hline $\begin{array}{l}\text { Independent } \\
\text { Variables }\end{array}$ & $\begin{array}{l}\boldsymbol{Y}=\text { gross earnings } \\
\text { per pound }\end{array}$ \\
\hline Constant & $0.526^{*}$ \\
Co-op Policy & $0.214^{*}$ \\
t-statistic & $(2.22)$ \\
Fishery-Wide TAC & $-1.17 \mathrm{e}-06^{*}$ \\
Fixed Effects & $(2.14)$ \\
\hline Year Dummies & Included \\
Fishery Dummies & Included \\
Observations & 66 \\
Adjusted $\mathrm{R}^{2}$ & 0.814 \\
\hline
\end{tabular}

Notes: (1) * Significant at 0.05 level for a one-tailed t-test. (2) Year and fishery dummies are as in Table 1. (3) The gross earnings data are adjusted by the CPI and are presented in 2008 dollars. (4) Data are available at: http://www.cfec.state.ak.us/research/salmon/salpmt98_07.pdf and http://www.cfec.state.ak.us/research/salmon/salpmt99 08.pdf.

\section{Public Input Provision}

Our evidence on provision of shared or public inputs by the co-op is anecdotal, gleaned from trade press accounts and annual management reports of the Alaska Department of Fish and Game (ADFG). The most prominent shared inputs installed by the co-op were 'fixed leads', stationary nets placed along the fish migration route to funnel the stock toward waiting purse seiners. ${ }^{46}$ The fixed leads altered the style of fishing and dramatically reduced the number of vessels required to achieve a given catch. This sort of shared infrastructure was not employed by the independent fleet. ${ }^{47}$

Other actions we characterize as public good provision by the co-op amount to very precise coordination of members' actions. An important form of coordination was a finely tuned

before the co-op years, during the co-op years, and after the co-op years. This approach generates consistent standard error estimates (Bertrand et. al. 2004). The resulting coefficient on the Co-op Policy for the collapsed data is 0.211 with a t-statistic of 2.16 .

${ }^{45}$ We lack cross-section data during 2002-2004 that would allow us to compare output prices between the co-op and independent sectors.

${ }^{46}$ See Pappas and Clark (2003).

${ }^{47}$ Ross (2002a). 
temporal allocation of its members' effort (Stichert, 2007). During low tides in Chignik Lagoon, the inside location where the co-op harvested, shrinks to a fraction of its size at high water. This concentrates the fish and reduces harvest cost. A prominent co-op member described how this strategy worked:

"Instead of [a co-op member] making four or five sets ... during the flood [high tide] for 200 to 300 [fish] a haul, he now could wait till the Lagoon drained out. At low tide ... [the channel] became a slow, meandering river of concentrated sockeye. And now, fishing for the entire co-op, he could make one giant drag for 3,000 to 5,000 fish. ${ }^{48}$

This strategy required that co-op harvesters allow fish to escape up river during high tides, even though it is legal to catch them. Given the co-op's secure catch allocation and its ability to coordinate, however, the incentive to do this was present. We know of no instances of independent fishermen intentionally allowing fish to swim up river.

The co-op also coordinated its members' actions to improve the quality of fish delivered to processors. It received permits to hold live fish in net pens for up to three days, which allowed it to better match deliveries to processing capacity. On occasion, the co-op even released live fish from capture when processing capacity was insufficient. ${ }^{49}$ Independent harvesters have no incentive to engage in such practices and we are aware of no evidence indicating that they did. The co-op also coordinated information on stock locations from all of its active members and used this information to dispatch vessels and crews to the most advantageous locations. We are aware of no evidence that the independent fleet followed this practice; indeed, fishermen are notorious for hiding such information from their competitors.

Finally, the fishery manager also benefited from the co-op's ability to coordinate, by enabling precise control of a day's catch in ways that cannot be accomplished with independent fishing. With independent fishing the fishery manager must forecast the rate of catch and announce a closing time calculated to meet the overall catch target, an imprecise process at best. On days the co-op fished, the manager could hit the target precisely, simply by requesting that the co-op cease fishing when the desired number of fish was caught (Pappas and Clark, 2003).

\section{Who Joined and Who Fished for the Co-op?}

Our model addresses these two key questions and yields the following predictions: highliners will remain independent while less-skilled fishermen will opt into the co-op (Prop.3.i)

\footnotetext{
${ }^{48}$ Ross (December 2002).

${ }^{49}$ The preceding two examples are from: Mark A. Stichert, 2004 Chignik Management Area Annual Management Report. Alaska Department of Fish and Game, at: http://www.sf.adfg.state.ak.us/FedAidPDFs/fmr07-15.pdf. (2007)
} 
and the co-op will deploy its highest skilled members to fish on behalf of the entire enterprise (Prop.1.ii). Our model suggests that historic catch is a good proxy for the critical skill parameter, $\gamma$, so we test these predictions with data on catch shares during the pre-co-op period.

While individual catch shares are not disclosed due Alaska confidentiality laws, we were able to obtain catch share data aggregated to the three firm level. ${ }^{50}$ The procedure for carrying out these aggregations was designed to minimize catch share heterogeneity among the observations that were grouped. Because some harvesters changed status during the co-op period, different aggregations were formed, using the same procedure, for 2002, 2003 and 2004. For 2002 aggregations, individual fishermen were first partitioned into three groups depending on their 2002 co-op status: co-op joiners who fished, non-fishing co-op joiners and independents. All fishermen in a given group were ordered by average sockeye catch share over the historic 19952001 period. $^{51}$ Successive fishermen were then clustered into groups of three and the average historic catch share within each cluster was reported to us. This procedure was then repeated for groups formed on the basis of 2003 and 2004 co-op status. The end result was a set of roughly 100 observations on co-op status each year during 2002-2004 and average historic catch share (for 3-firm aggregates) during 1995-2001. We examine the model's predictions both by testing for differences in mean historic catch shares across groups and by testing for stochastic dominance in the historic catch share distributions of different groups. ${ }^{52}$

Table 5 presents comparisons of mean historic catch shares. The first set of comparisons indicates that the mean historic catch share of those who fished independently during 2002-2004 significantly exceeded that of co-op joiners (1.29 percent compared to 1.00 percent). The second

\footnotetext{
${ }^{50}$ We are indebted to the Alaska Commercial Fisheries Entry Commission for performing these aggregations for us. In a few cases it was necessary to aggregate over four firms.

${ }^{51}$ We do not consider more distant catch histories because vessel attributes and skill levels can change over time; we do not consider other salmon species because the co-op fished exclusively for sockeye.

${ }^{52}$ The premise underlying these empirical tests, that catch shares in the pre-co-op (historic) period are a good indicator of skill, deserves further discussion. The pre-cooperative period in the fishery corresponds to the independent sector's second stage subgame where all fishers choose distance and fishing times independently and face a common season length. The model indicates that all permit holders will choose to fish the entire season in this circumstance. In a symmetric Nash equilibrium, where all fish at the same distance, all obtain the same catch per unit effort and in this case the correspondence between skill and catch shares is precise. To see this, let $\tilde{A}$ indicate catch per unit effort and $\widetilde{T}$ the season length; fisherman i's catch is then $\tilde{A} \gamma_{i} \widetilde{T}$, which is proportional to i's skill. In a mixed equilibrium, where some fish inside and some fish outside, the correspondence is not exact unless all fishermen split their fishing time between the two locations in the same proportion. This is true because inside effort achieves a lower catch per unit effort than outside effort. If skill were correlated with choice of location, historic catch shares would partly reflect location choices and not just skill. We see no reason for a correlation between skill and location choice correlation, however, because equilibrium profit per unit effort is the same at both locations. For this reason we regard historic catch share as an unbiased but possibly imprecise indicator of skill in the mixed equilibrium case.
} 
set indicates that the mean historic catch share of those who fished for the co-op exceeded the mean for non-fishing co-op members (1.11 percent compared to 0.90 percent). Both results agree with predictions.

\section{Table 5}

Comparison of Mean Catch Histories for Ranked and Sorted Clusters of Fishermen

\begin{tabular}{lccc}
\hline & \# of Obs. & $\begin{array}{c}\text { Mean } \\
\text { Catch Share }\end{array}$ & $\begin{array}{c}\text { t-stat for diff. } \\
\text { (abs. value) }\end{array}$ \\
\hline $\begin{array}{l}\text { Independents v. All Joiners } \\
\text { Independents }\end{array}$ & 18 & 1.29 & $2.90^{*}$ \\
All co-op members & 78 & 1.00 & \\
Fishing vs. Non-fishing Co-op Joiners & 18 & & $1.83 *$ \\
Co-op members who fished & 59 & 1.11 & \\
Co-op members who did not fish & & & \\
& & & \\
\hline Notes: * statistically significant at 0.05 level for a one-tailed test. The data used here are pooled for \\
2002-2004.
\end{tabular}

Tests for first-order stochastic dominance in the empirical distribution functions also agree with predictions. Figure 7 a plots the harvest share cumulative density functions for joiners and independents using the ranked and clustered data just described. From visual inspection, the empirical CDF for independents stochastically dominates that for joiners, i.e., the fraction of observations with catch share value less than or equal to a given value is greater for c-op joiners than for independents, for all observed catch share values. In Figure $7 \mathrm{~b}$ we see that, except for a single exception near the right tail, the empirical CDF for co-op fishers stochastically dominates that for non-fishing co-op members. Kolmogorov-Smirnov tests confirm that the differences in the CDFs are statistically significant by conventional standards. ${ }^{53}$

\footnotetext{
${ }^{53}$ The test results are available from the authors.
} 

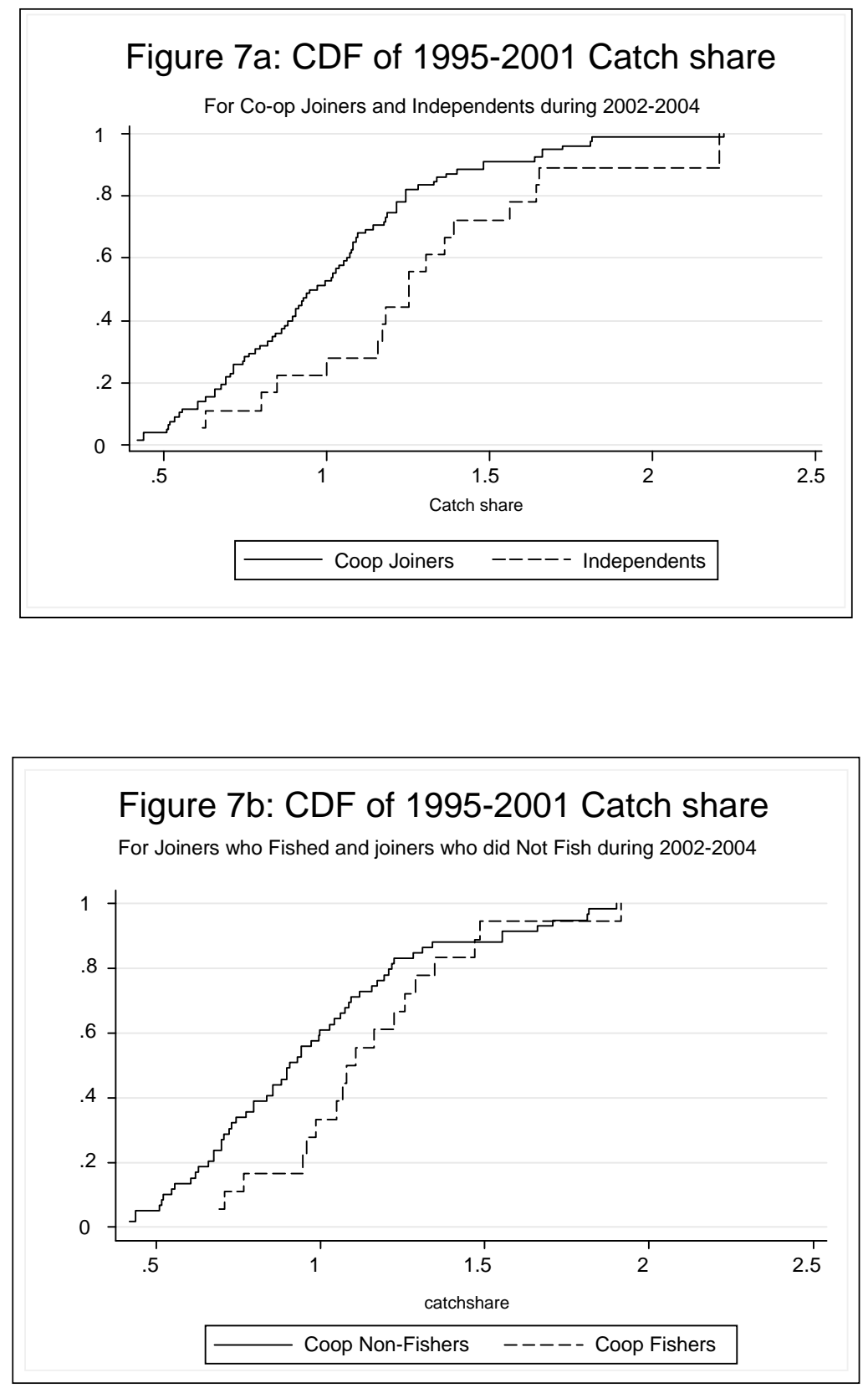

\section{Value of the Fishery}

A remaining question is: how were profits in the fishery affected by allowing the co-op to form? We lack data on individual firm-level profits, but we do have data on the value of fishing permits. The value of a Chignik fishing permit should reflect the expected present value profit that a marginal (low skill) fisherman could earn in this fishery. The marginal fisherman's profit is relevant, rather than the highliner's profit, because (ignoring differences in non-pecuniary returns) the marginal fisherman would have the lowest reservation price for selling a permit, and would therefore determine the transaction price to potential buyers. 
Table 6 shows our estimate of the effect of the co-op policy on permit value using the same panel-regression model and controls used in Tables 1 and 4 . The result indicates that the co-op policy increased the value of a permit by $\$ 48,814$ in 2008 dollars. This is a 26.3 percent increase relative to $\$ 185,806$, which was the mean value of a Chignik permit over 1998 to 2008 excluding the coop years. ${ }^{54}$

\section{Table 6 \\ Panel Regression of Permit Value (in 2008 dollars)}

\begin{tabular}{lc}
\hline $\begin{array}{l}\text { Independent } \\
\text { Variables }\end{array}$ & $\boldsymbol{Y}=$ permit value \\
\hline Constant & 7,962 \\
Co-op Policy & $48,814^{*}$ \\
t-statistic & $(2.32)$ \\
Fishery-Wide TAC & -0.051 \\
Fixed Effects & $(0.43)$ \\
Year Dummies & Included \\
Fishery Dummies & Included \\
Observations & 66 \\
Adjusted $\mathrm{R}^{2}$ & 0.873 \\
\hline
\end{tabular}

Notes: (1) * Significant at 0.05 level for a one-tailed t-test. (2) Year and fishery dummies are as in Table 1. (3) The permit value data are adjusted by the CPI and are presented in 2008 dollars. (4) Data are available at: http://www.cfec.state.ak.us/research/salmon/salpmt98_07.pdf and http://www.cfec.state.ak.us/research/salmon/salpmt99 08.pdf.

We translate the permit value effect into an annual profit effect, as follows. The permit value difference in Table 6 presumably reflects the co-op's effect on the present value of expected future profit for the marginal harvester. While it was operating, however, the co-op's life span was unknown. We deal with this uncertainty by estimating a range of values for the implied annual profit effect, each based on a different assumption about the co-op's expected life span. The lawsuit that eventually ended the co-op was filed in April 2002 (Grunert v. State 2005, p. 928), just before its first year of operation. We therefore set the lower bound life expectancy at

\footnotetext{
${ }^{54}$ As before we estimate a version of the regression in Table 6 by collapsing the data into averages for each fishery during three time periods - before the co-op years, during the co-op years, and after the co-op years. This approach generates consistent standard error estimates (Bertrand et. al. 2004). In our case, the coefficient on the Co-op Policy for the collapsed data is 49,024 with a t-statistic of 1.48.
} 
3 years, its actual period of operation. We set the upper bound at infinity, corresponding to an expectation that it would persist in perpetuity.

The estimated profit effect is calculated as follows. Let $\pi$ indicate the expected annual profit before the co-op formed, and assume it is constant; let $V$ indicate the pre-co-op license value and let $r$ be the interest rate. Assuming license values observed before the co-op formed did not incorporate expected profits from the co-op's possible formation, the preceding variables are linked by $V=\pi / r$. Let $\Delta V$ be the change in license value resulting from the co-op's formation, which we estimate, and let $T$ indicate the number of years the co-op was expected to operate. We wish to estimate the proportionate change in profit resulting from allowing the co-op to form, $\Phi$. The appropriate present value formula gives $\Delta V=\{\Phi \pi / r\} \cdot\left\{1-1 /(1+r)^{T+1}\right\}^{-1}$. The term of interest, $\Phi$, can now be found by combining the two preceding expressions: $\Phi=\Delta V / V \cdot\left\{1-1 /(1+r)^{T+1}\right\}^{-1}$.

\begin{tabular}{l}
$\begin{array}{l}\text { Table } 7 \\
\text { Proportionate profit increase from allowing co-op to form }\end{array}$ \\
\begin{tabular}{lrrrrr}
\hline Increase in license value & $\$ 48,814$ & & & \\
Baseline license value & $\$ 185,806$ & & & \\
\hline Coop operating horizon (years) & 3 & 5 & 10 & $\infty$ \\
\hline $\begin{array}{l}\text { Proportionate profit gain }(\Phi) \\
(r=.10)\end{array}$ & 0.83 & 0.60 & 0.40 & 0.26 \\
$\begin{array}{l}\text { Proportionate profit gain }(\Phi) \\
(r=.07)\end{array}$ & 1.11 & 0.79 & 0.50 & 0.26 \\
\hline
\end{tabular} \\
\hline
\end{tabular}

Applying this formula to the data yields the results in Table 7. The lower-bound estimate of the annual gain in the marginal fisherman's profit due to the co-op's formation is 26 percent. If parties bidding for Chignik licenses thought the co-op would last for 5 years, the implied proportionate effect on annual profit is 60-79 percent and other entries in Table 7 have similar interpretations.

\section{Pareto Improvements, the TAC Allocation Rule and the Co-op Lawsuit}

Our empirical evidence on the question of Pareto improvements consists of data on the historic catch of co-op joiners and independents, the regulator's TAC allocation rule and the lawsuit that challenged the co-op. Our model (Prop. 4i) indicates that dividing the TAC between 
the co-op and independent sectors in proportion to aggregate skill, corresponding to $\theta=\theta_{c}$, would make those who choose to join the co-op better off and leave those who choose to fish as independents indifferent. This is a 'knife-edge' Pareto improvement, however; even a slight deviation from this TAC division that disfavors the independents $\left(\theta>\theta_{c}\right)$ would make all independents worse off, and presumably cause them to oppose the co-op's formation.

The allocation rule set forth when the co-op was first authorized (described at the beginning of this section) resulted in a TAC share for the co-op of 0.693 in 2002, its first year of operation. This share resulted from having 77 joiners and a nine-tenths per capita share $(\theta=0.9)$ for each $(77 \times 0.9=.693)$. Our model indicates that historic, pre-co-op, catch is a natural measure of skill. The aggregate historic (1995-2001) catch share of those who chose to join in 2002 was within 1 percentage point of the co-op's assigned TAC share.

Based on the model, therefore, it appears that this outcome and the essentially identical outcome in 2003 were right on the knife's edge for a Pareto improvement. By 2004, however, the number of co-op joiners had increased from 77 to 87 . To ensure a Pareto improving outcome as the size of the independent fleet declined, the TAC allocation granted for each independent permit holder would need to be increased (i.e. $\theta$ would need to decline). This is true because those leaving the independent sector to sign on with the co-op would be the least skilled independents (Prop. 3); hence, those remaining would be the most skilled independents. The actual allocation formula did just the opposite. Once the number of co-op members reached 85 in 2004, the allocation rule reduced the independent sector's TAC share to coincide with the proportion of permit holders that chose to fish independently. This corresponds to an allocation based on $\theta=1$ which, according to our model, disadvantages all independents. Rough calculations indicate that it would have been necessary to increase the independent sector's per capita TAC allocation by at least $10 \%$ to ensure a Pareto improvement; instead it was reduced by $40 \%$.

The lawsuit challenging the co-op policy was filed by Michael Grunert and Dean Anderson. Consistent with the model's predictions, both were among the highest earning Chignik permit holders and neither joined the co-op. The fact that Grunert and Anderson filed the lawsuit in 2002 suggests that they assigned a positive probability to the number of joiners growing over time to the point where highliners would become disadvantaged, which clearly seems to be what happened by 2004. 


\section{Conclusions}

We have modeled the potential gains from coordinating the actions of common pool extractors and presented empirical evidence on these gains in the context of the fishery. Much of the received literature on fishery management emphasizes the ability of market-based instruments such as individual catch shares (ITQs) to eliminate redundant fishing units and end wasteful races that result from the rule of capture. We extend this work by demonstrating that the value of a common pool resource can be further enhanced by coordinating the actions of extractors. While individual rights holders lack incentives to coordinate, a harvesting group with the contractual authority to direct its members' inputs can be structured to capture these gains, essentially by acting as a single firm. Coordination gains result from providing public inputs such as shared infrastructure and shared information on stock locations and from coordinating harvesters' actions over space and time in cases where the value of stock varies over these dimensions. Our empirical results from the Chignik case indicate that the efficiency gains can be substantial.

Allocating a portion of the allowed catch to a group of harvesters to manage as they see fit within broad constraints is a growing trend in fishery management. Examples from the U.S. are recently formed sector allocations for groundfish in the New England region, allocations to cooperatives for harvesting Alaska pollock and Pacific Whiting and the Chignik cooperative examined here. The reasons cited for this trend include points emphasized here: the relative ease of assigning rights among a few sectors and the gains from coordinating effort. ${ }^{55}$

The lawsuit that ended the co-op highlights a consideration seldom mentioned in the literature on common pool management - the value and difficulty of designing policy in a way that enables reform without losers. In the Chignik case, the question of whether or not the co-op's formation would lead to a Pareto improvement was determined by three factors: the fact that joining the co-op was voluntary, the regulator's rule for dividing the allowed catch between co-op and independent sectors, and the co-op's internal rule for sharing profits. The co-op's voluntary nature was advantageous because it provided a vehicle for limiting individual losses by allowing any dissenting parties to continue under a regime that resembled the status quo. To achieve actual loss avoidance, however, required a precise division of the allowed catch between sectors and this

55 Sullivan (2000) comments on the ease of assigning catch shares among members of two important fishing cooperatives. Evidence from New Zealand demonstrates that coordinating entities can be layered onto existing individual catch share systems, by allowing quota holders to form associations of harvesters to coordinate their actions. In New Zealand's paua (abalone) and sea scallop fisheries, harvester groups have formed associations (or a single firm in the case of scallops) that allocate effort spatially, share information on stock densities, support research and stock enhancement efforts and carry out other actions that benefit the fishery as a whole. None of these actions is in the interest of any single harvester. 
was complicated by the fact that individuals self-selected into the two sectors on the basis of skill. In the Chignik case, higher skill fishermen chose to remain independent, necessitating that this sector receive a disproportionately large catch allocation. While the actual division incorporated this to a degree, it apparently did not go far enough. Finally, it is clear that the co-op could have altered its equal-profit share rule in a way that would have gained more support from high skill fishermen. ${ }^{56}$ The co-op's founders considered alternative profit share rules in initial deliberations, but these negotiations proved difficult. In the end a simple equal division rule was adopted. Despite evidence of potential gains from various forms of rights-based management, ${ }^{57}$ less than $2 \%$ of the world's fisheries currently employ the most prominent rights-based regime, the individual catch share. At least three factors account for this dearth of implementation. First, incumbent fishermen often vocally oppose catch shares on the grounds that they eliminate "free" access to the resource. Second, the initial allocation of rights invites rent-seeking contention. Third, the individual transferable quota (ITQ) model that has achieved some success in Alaska, Iceland, New Zealand, and elsewhere, may still leave significant rents on the table by failing to achieve potential gains from coordinating the actions of independent quota holders.

The rights-based approach exemplified by the Chignik experiment, with catch rights assigned to groups formed voluntarily, makes progress toward overcoming each of these impediments. It helps to defuse the right to fish argument by offering all participants the right to opt into a sector governed by the status quo management regime. While it does not eliminate wasteful struggles over the initial allocation, it arguably reduces the magnitude of the problem by assigning to voluntary groups the task of negotiating catch shares among their members, while requiring the regulator only to make the gross division of catch between sectors. Finally, by enabling coordination among individuals this approach can substantially increase rents in the fishery, making the often contentious process of reform a more lucrative positive sum game than it otherwise would be.

\footnotetext{
${ }^{56}$ In fact, one of the two highliners who filed the suit that ended the co-op has argued in favor of a fishery management approach in which all harvesting is by cooperatives and co-op profits are shared in proportion to historic catch shares. See Anderson (2002).

${ }^{57}$ Evidence in favor of rights-based management is extensive. Hannesson (2004) provides a broad review of theoretical and empirical work. Grafton et al. (2000) found large increases in rents associated with introducing a right-based system for Canadian Halibut. Leal (2002) surveys several US and Canadian ITQ programs and finds similar effects. Linn et al. (2008) estimate that introducing a rights-based system for west coast groundfish in the U.S. could reduce costs by 60 percent, some $\$ 18-\$ 20$ million annually. Newell et al. (2005) document significant annual rents in New Zealand's many ITQ programs. Costello et al. (2008) document reductions in collapse from ITQs.
} 


\section{References}

Anderson, Dean, 2002. "There's More than One Way to Craft a Co-op." Alaska Fisherman's Journal, December: 52-57.

Barrett, Scott, 1994. Self-enforcing International Environmental Agreements," Oxford Economic Papers, Vol. 46: 878-894.

Beddington, JR, Agnew, DJ, Clark, CW, Current problems in the management of marine fisheries., Science, 2007, Vol: 316, Pages: 1713 - 1716

Bertrand, Marianne, Duflo, Esther and Sendhil Mullainathan. 2004. How Much Should we Trust Difference-in-Difference Estimates? Quarterly Journal of Economics: 249-275.

Bouwens, Kenneth and Aaron Poetter. 2006. 2002 Chignik Management Area Annual Management Report. Alaska Department of Fish and Game. Available at: http://www.sf.adfg.state.ak.us/FedAidPDFs/fmr06-21.pdf

Bouwens, Kenneth and Mark. A. Stichert. 2006. 2004 Chignik Management Area Annual Management Report. Alaska Department of Fish and Game. Available at:http://www.sf.adfg.state.ak.us/FedAidPDFs/fmr06-69.pdf

Boyce, J. 1992. Individual Transferable Quotas and Production Externalities in a Fishery. Natural Resource Modeling 6(4):385-408.

Coase, Ronald H. (November 1937). "The Nature of the Firm". Economica 4 (16): 386-405.

Cornes, Richard, and Todd Sandler, 1996. The Theory of Externalities, Public Goods and Club Goods, $2^{\text {nd }}$ Ed., Cambridge: Cambridge University Press.

Costello, Christopher, Steven D. Gaines and John Lyhnam, 2008. Can Catch Shares Prevent Fisheries Collapse? Science Vol. 321 (September 19, 2008): 1678-1681.

Costello, Christopher and Robert T. Deacon. 2007. The Efficiency Gains from Fully Delineating Rights in an ITQ Fishery, Marine Resource Economics Vol. 22: 347-361.

d'Aspremont, Claude, Alexis Jacquemin, Jean Jaskold Gabszewicz, and John A. Weymark, 1983. "On the Stability of Collusive Price Leadership," Canadian Journal of Economics, Vol. XVI, No. 1: 17-25.

Deacon, Robert T., Dominic P. Parker and Christopher Costello, 2008. Improving Efficiency by Assigning Harvest Rights to Fishery Cooperatives: Evidence from the Chignik Salmon Coop, Arizona Law Review Vol. 50 (Summer 2008): 479-510.

da Silva, P. P, and A. W. Kitts, 2006. "Collaborative Fisheries Management in the Northeast US: Emerging Initiatives and Future Directons." Marine Policy 30 832-841.

Gordon, H.S. 1954. The theory of a common property resource: the fishery, J. Polit. Economy 62: $124-142$.

Grafton, R. Quentin, et al, 2006. Incentive-based Approaches to Sustainable Fisheries, Canadian Journal of Fisheries and Aquatic Science Vol. 63: 699-710.

Grafton, R, D. Squires, and K. Fox. Private property and economic efficiency: A study of a common pool resources. The Journal of Law and Economics. 43: 679-713.

Griffith, David. 2007. The ecological implications of individual fishing quotas and harvest cooperatives. Frontiers in Ecology and the Environment. 6(4): 191-198. 
Grunert v. State, 109 P.3d 924, Alaska 2005, p. 924 -941.

Halpern et al. 2008. A global map of human impact on marine ecosystems. Science. 319(5865): 948-952.

Hamilton, Barton H., Jack A. Nickerson and Hideo Owan, 2003. "Team Incentives and Worker Heterogeneity: An empirical Analysis of the Impact of Teams on Productivity and Participation.” Journal of Political Economy, Vol. 111,No. 3 (June 2003): 465-497.

Hannesson, R. 2004. The Privatization of the Oceans. MIT Press.

Hilborn, R., J. M. Orensanz, and A. M. Parma. 2005. Institutions, incentives and the future of fisheries. Philosophical Transactions of the Royal Society of London Series B-Biological Sciences, 360:47-57

Jackson et al., 2001 J.B.C. Jackson et al., Historical overfishing and the recent collapse of coastal ecosystems, Science 293 (2001), pp. 629-638.

Johnson, R. and G. Libecap. 1982. Contracting problems and regulation: the case of the fishery. American Economic Review. 72(5): 1005-1022.

Kitts, A. W., and S. F. Edwards, forthcoming. K"Cooperatives in US Fisheries: Realizing the Potential of the Fishermen's Collective Marketing Act." Marine Policy.

Knapp, G. and L. Hill. 2003. Effects of the Chignik Salmon Cooperative: What the Permit Holders Say. UA Research Summary. June.

Knapp, Gunnar; Siver, Darla; Deroche, Pat, and Alexandra Hill. 2002. "Effects of the 2002 Chignik Salmon Cooperative: A Survey of Chignik Salmon Permit Holders.” ISER Report, University of Alaska Anchorage. Available at: http://www.iser.uaa.alaska.edu/Publications/ISERChignikSurveyReportpt1.pdf

Knapp, Gunnar and Lexi Hill. 2003. "Effects of the Chignik Salmon Cooperative: What Permit Holders Say." UA Research Summary No. 1. ISER, University of Alaska Anchorage. Available at: http://www.alaskaneconomy.uaa.alaska.edu/Publications/SummaryEffectsChignik.pdf

Kolstad, Charles, and Alastair Ulph, 2008. "Learning and International Environmental Agreements." Climatic Change Vol 89:125-141.

Lau, Lawrence J., Yingyi Qian, and Gerard Roland, 2000. "Reform without Losers: An Interpretation of China's Dual-Track Approach to Transition," Journal of Political Economy, Vol. 108, No. 1: 120-141,

Leal, Donald R. Ed. 2004. Evolving Property Rights in Marine Fisheries. Rowman \& Littlefield Publishers, Inc. Lanham, MD.

Leal, Donald R., 2002. Fencing the Fishery: A Primer on Ending the Race for Fish, Property and Environment Research Center, Bozeman, MT.

Libecap, Gary, and Steven N. Wiggins, 1984. "Contractual Responses to the Common Pool: Prorationing of Crude Oil Production," American Economic Review, Vol. 74, No. 1 (March 1984): 87-98.

Linn, Singh, Weninger. 2008. Placeholder $<$ Estimate effects on costs of west-coast ITQ $>$

Matulich, Scott C., Murat Sever and Fred Inaba, 2001. "Fishery Cooperatives as an Alternative to ITQs: Implications of the American Fisheries Act." Marine Resource Economics (16) 1-16. 
Meyer, Bruce D., 1995. "Natural and Quasi-Experiments in Economics", Journal of Business and Economic Statistics, Vol. 13, no. 2. 151-161.

Myers RA, Worm B (2003) Rapid worldwide depletion of predatory fish communities. Nature 423:280-283

Newell, R.G., J.N. Sanchirico and S. Kerr., Fishing Quota Markets, Journal of Environmental Economics and Management, vol. 49 (2005), pp. 437-462

Ostrom, E. 1990. Governing the Commons. Cambridge University Press.

Pappas, George and Kevin Clark. 2003. Chignik Management Area Commercial Salmon

Fishery, Stock Status, and Purse Seine Cooperative Fishery Report. Report to the Alaska Board of Fisheries. Available at: http://www.cf.adfg.state.ak.us/region4/pubs/2003/nov bof/4k03-54.pdf

Provencher, Bill, and Oscar Burt, 1994. "A Private Property Rights Regime for the Commons: The Case for Groundwater," American Journal of Agricultural Economics, Vol. 76 (November 1994): 875-888.

Ross, Jamie, 2002a. Inside the Co-op, Part I: Radical Surgery Prevents Slow Death, Alaska Fisherman's Journal, November 2002.

Ross, Jamie, 2002b. Inside the Co-op, Part II: The Chignik Fishery and the Aftermath, Alaska Fisherman's Journal, December 2002.

Schelle, Kurt, Carlson, Stefanie, and Nancy Free-Sloan. 2002. Chignik Salmon Purse Seine Fishery: Summary Data on Issues Related to the 2002 Cooperative Fishery. Report Prepared for he Alaska Board of Fisheries. Available at: http://www.cfec.state.ak.us/research/02_6n/chigcoop.pdf

Scott, A. 1955. The fishery: the objectives of sole ownership, J. Polit. Economy 63: 116-124.

Scott, Anthony, 2000. Moving Through the Narrows: From Open Access to ITQs and Selfgovernment. In Ross Shotton ed., Use of Property Rights in Fisheries Management, FAO Fisheries Technical Paper 404/1, at 114-15.

Stichert, Mark A. 2007. 2004 Chignik Management Area Annual Management Report. Alaska Department of Fish and Game. Available at: http://www.sf.adfg.state.ak.us/FedAidPDFs/fmr07-15.pdf.

Sullivan, J. M. 2000. "Harvesting Cooperatives and US Antitrust Law: Recent Developments and Implications.” Accessed at: http://oregonstate.edu/Dept/IIFET/2000/papers/sullivan.pdf.

Tietenberg, Tom, 2002. The Tradable Permits Approach to Protecting the Commons: What Have We Learned? In Ostrom, Elinor, et al, The Drama of the Commons. Washington DC: National Academy Press.

Townsend, R. E. 2004. Producer Organizations and Agreements in Fisheries: Integrating Regulation and Coasean Bargaining. In Evolving Property Rights in Marine Fisheries, Ed. D. Leal. Rowman \& Littlefield Publishers, Inc. Lanham, MD.

Townsend, R. E., 1995. "Fisheries Self-Governance: Corporate or Cooperative Structures?" Marine Policy 19(1) 39-45.

Wiggins, Steven N., and Gary Libecap, 1985. "Oil Field Unitization: Contractual Failure in the Presence of Imperfect Information," American Economic Review, Vol. 75, No. 3 (June 1985): 368-385. 
Wilen, James. 2006. TURFs and ITQs: Coordinated vs. Decentralized Decision Making. Paper presented at the Workshop on Advances in Rights-based Fisheries Management, Reykjavik, Iceland, August 2006.

Wilen, James E., 2005. Property Rights and the Texture of Rents in Fisheries. In Donald R. Leal, ed. Evolving Property Rights in Marine Fisheries Oxford: rowman \& Littlefield Publishers, Inc.

Wilson, J. 1990. Fishing for knowledge. Land Economics: 66(1) 12-29.

Worm B, Barbier EB, Beaumont N, Duffy JE, Folke C, Halpern BS, Jackson JBC, Lotze HK, Micheli F, Palumbi SR, Sala E, Selkoe K, Stachowicz JJ, Watson R (2007b) Response to comments on 'Impacts of biodiversity loss on ocean ecosystem services'. Science 316:1285

Worm, B., R. Hilborn, J. Baum, T. Branch, J. Collie, C. Costello, M. Fogarty, E. Fulton, J. Hutchings, S. Jennings, O. Jensen, H. Lotze, P. Mace, T. McClanahan, C. Minto, S. Palumbi, A. Parma, D. Ricard, A. Rosenberg, R. Watson, and D. Zeller. 2009. Rebuilding global fisheries. 325: 578-585.

Yandle, Tracy, 2003. "The Challenge of Building Successful Stakeholder Organizations: New Zealand's Experience in Developing a Fisheries Co-management Regime," Marine Policy 27 179-192. 
Appendix

\section{A.1 Co-op's optimal policy}

The co-op's optimal allocation minimizes

$$
\min _{d_{i}, T_{i}} F_{i \in J ; x_{J}}^{-1}(\beta) Z_{J} \alpha+F^{-1}(\beta) Z_{J} \sum_{i \in J} d_{i}-\left\{F^{-1}(\beta) Z_{J} G\left(x_{J}\right)-x_{J}\right\}+\sum_{i \in J} \phi_{i} T_{i}
$$

subject to $\sum_{i \in J} \gamma_{i} T_{i}=F^{-1}(\beta) Z_{J}, d_{i} \in\{0, \bar{d}\}, T_{i} \in\left[0, T_{J}\right]$ for all $i$, and $T_{J} \leq \bar{T}$. Since (A.1) is strictly increasing in $d_{i}$ the optimal policy sets $d_{i}=0$ for each member. The term in brackets is the net benefit that the public input provides. Given assumed properties of $G\left(x_{J}\right)$ the following first-order condition is necessary and sufficient for minimizing (A.1) with respect to $x_{J}$ :

$$
F^{-1}(\beta) Z_{J} G^{\prime}\left(x_{J}\right)-1=0
$$

This is the Samuelson condition for efficient public input provision.

It remains to find an assignment of member fishing times that minimizes the fourth term in (A.1), subject to the catch constraint. The catch constraint for group $J$ implies the following constraint on effort:

$$
\sum_{i \in J} \gamma_{i} T_{i} \leq Z_{J} F^{-1}(\beta)
$$

Index co-op members in increasing order of the ratio $\phi_{i} / \gamma_{i}$. Since $\phi_{i}$ and $\gamma_{i}$ are $i$ 's cost per unit time and effort per unit time respectively, this ratio is i's cost per unit effort. Consider a policy, denoted $\Lambda$, which assigns fishing time $\bar{T}$ to successive co-op members, in order of their index, until the constraint (A.3) is violated or satisfied with equality. If (A.3) is violated, let $\hat{i}$ indicate the highest indexed member in this low indexed subset and assign this member a fishing time that satisfies (A.3) exactly; all higher indexed members are assigned zero fishing time. This assignment satisfies the catch constraint by construction. To see that this assignment is cost minimizing, write the fourth term in (A.1) as $\sum_{i \in J} \frac{\phi_{i}}{\gamma_{i}} \gamma_{i} T_{i}$. The term $\gamma_{i} T_{i}$ is the fishing effort 
assigned to $i$ and the ratio is $i$ 's cost per unit effort. Any alternative to policy $\Lambda$ would require reducing $\gamma_{i} T_{i}$ by a lower indexed member and increasing $\gamma_{i} T_{i}$ in the same amount by a higher indexed member. Since the index orders members in terms of the ratio $\phi_{i} / \gamma_{i}$, this alternative assignment would necessarily result in higher total cost. Therefore the assignment of fishing times in policy $\Lambda$ is cost minimizing.

A.2 Public input benefit per member increases with co-op size

The public input confers a net benefit, per co-op member, of

$$
N B(n(J))=\frac{1}{n(J)}\left\{F^{-1}(\beta) Z \frac{n(J)}{n(K)} G\left(x_{J}\right)-x_{J}\right\} .
$$

Differentiating this with respect to $n(J)$ yields

$$
\begin{gathered}
\frac{\partial N B(n(J))}{\partial n(J)}=\frac{1}{n(J)}\left\{F^{-1}(\beta) \frac{Z}{n(K)}-\left(F^{-1}(\beta) Z \frac{n(J)}{n(K)} G^{\prime}\left(x_{J}\right)-1\right) \frac{\partial x_{J}}{\partial n(J)}\right\} \\
-\left\{F^{-1}(\beta) Z \frac{n(J)}{n(K)} G\left(x_{J}\right)-x_{J}\right\} \frac{1}{n(J)^{2}}
\end{gathered}
$$

Making use of the first-order condition (A.2) and simplifying, yields the desired result

$$
\frac{\partial N B(n(J))}{\partial n(J)}=\frac{x_{J}}{n(J)^{2}}>0
$$


Fig. A1

Map of Chignik Management Area on the Alaskan Peninsula

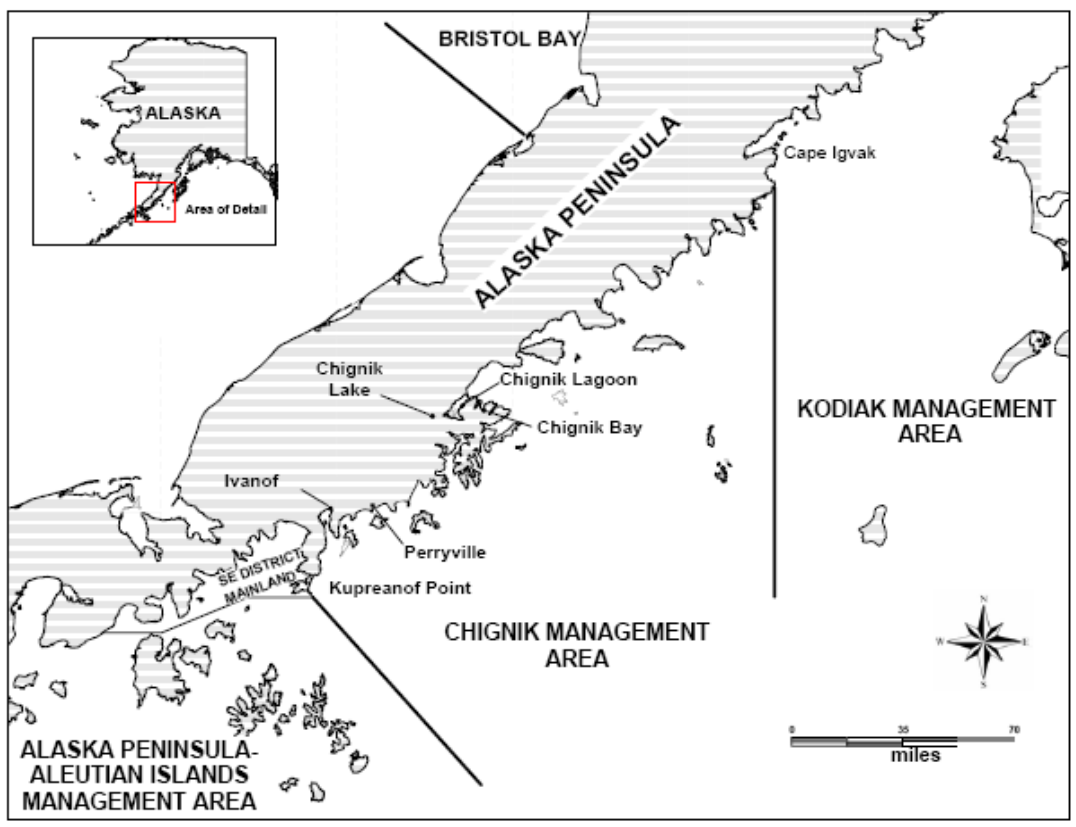

Source: Stichert (2007).

Fig. A2

Chignik Management Area with District Boundaries and Statistical Areas

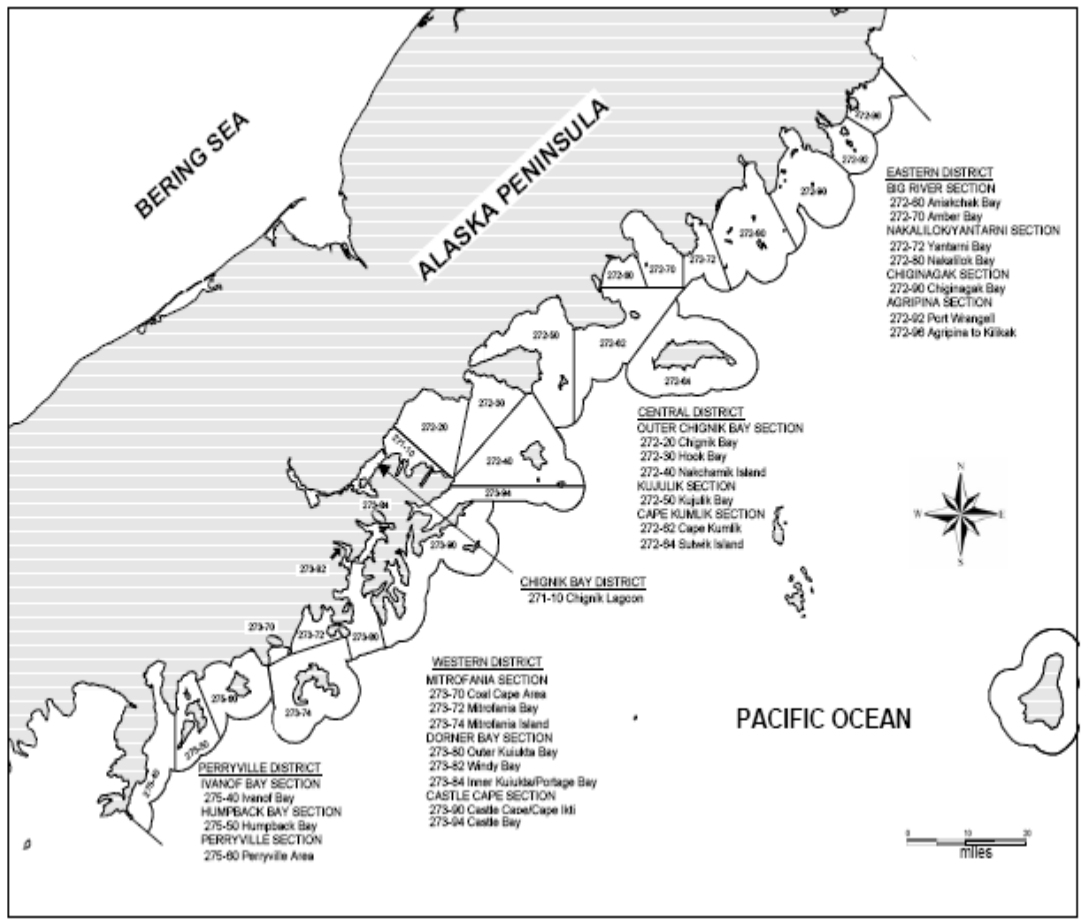

Source: Stichert (2007). 
Fig. A3

Map of Chignik Bay and Near Vicinities

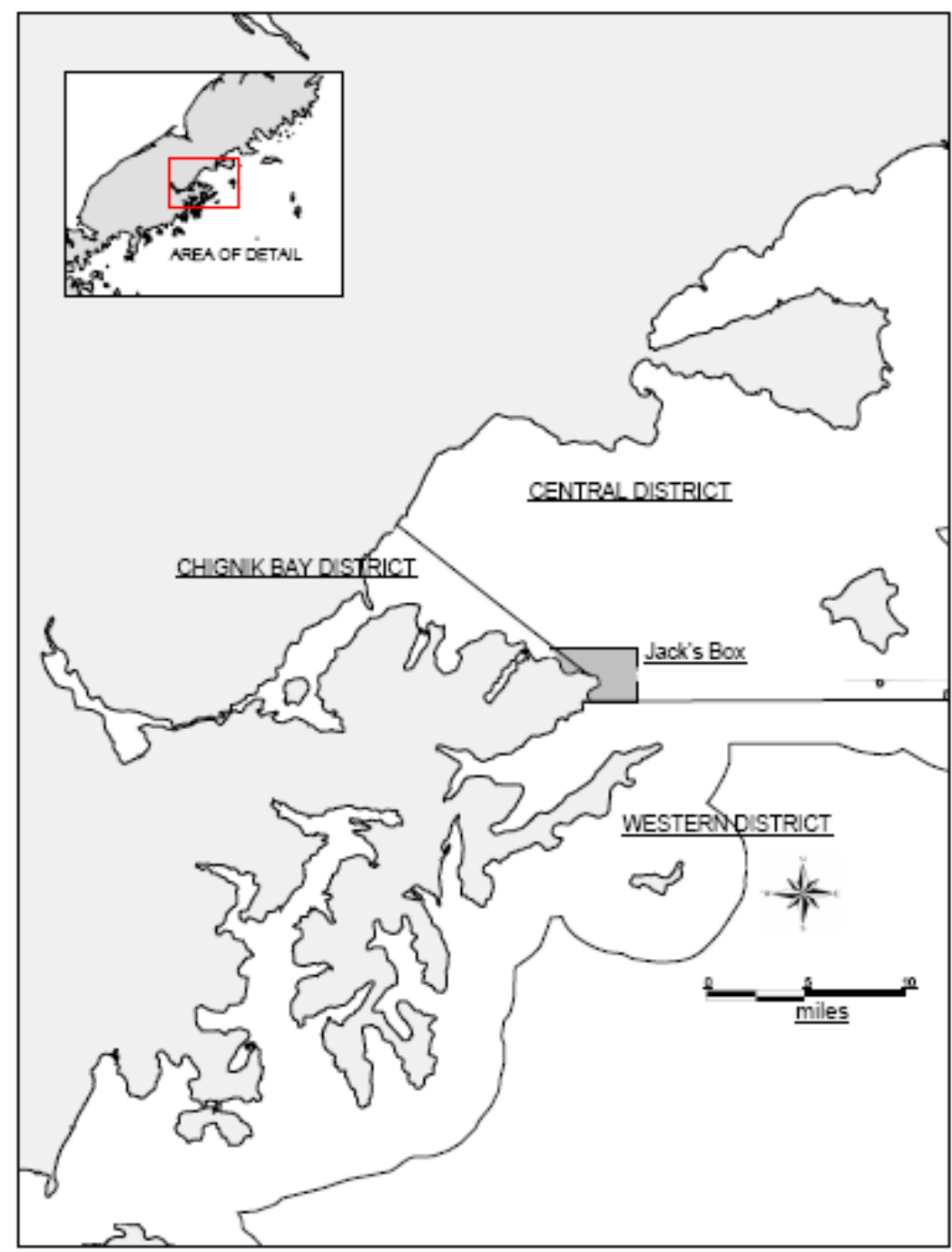

Source: Stichert (2007). 